Marquette University

e-Publications@Marquette

$2-1-2010$

Upheaval in the Boardroom: Outside Director Public Resignations, Motivations, and Consequences

Michael Dewally

Marquette University

Sarah Peck

Marquette University, sarah.peck@marquette.edu

Accepted version. Journal of Corporate Finance, Vol. 16, No. 1 (February 2010): 38-52. DOI.

Published under Creative Commons License CC BY-NC-ND 4.0. 


\title{
Upheaval in the Boardroom: Outside Director Public Resignations, Motivations, and Consequences ${ }^{\circ}$
}

\author{
Michaël Dewally \\ College of Business Administration, Marquette University \\ Milwaukee, WI \\ Sarah W. Peck \\ College of Business Administration, Marquette University \\ Milwaukee, WI
}

\begin{abstract}
We investigate the motives and circumstances surrounding outside directors' decisions to publicly announce their board resignations. Directors who leave "quietly" are in their mid-sixties and professional directors, i.e., retirees, who are retiring entirely from professional life. Directors who announce their resignation are in their mid-fifties and active professionals. Half the time they say they are leaving because they are "busy." These directors leave from firms with some weakness in their performance, but with no overt manifestations of cronyism such as excessive compensation of either the CEO or directors. The other half of the time directors leave while publicly criticizing the firm. These directors are finance professionals who were members of the audit and compensation committees. They resign from firms with weak boards and financial performance with evidence that managers have manipulated earnings upwards. Public criticism appears to pressure these boards to make management changes associated with improved stock price performance. We conclude that while such public resignations are motivated by the reputational concerns of directors, they can act as a disciplining device for poor board performance.
\end{abstract}


NOT THE PUBLISHED VERSION; this is the author's final, peer-reviewed manuscript. The published version may be accessed by following the link in the citation at the bottom of the page.

\section{Introduction}

In this study we examine announcements of outside director resignations to provide further insight into the incentives that outside directors have in monitoring managers. In their seminal work, Fama and Jensen (1983) argue that outside directors are expert decision makers and their incentives to monitor management stem from their desire to retain their reputation as experts. Outside directors are likely to resign publicly when they are no longer able to effectively watch over management, for whatever reason, as a way to keep their reputations. An investigation into the circumstances of public resignations can provide greater understanding into how directors and boards function.

Outside directors are charged to protect shareholders' interests. Yet, their ability to do so can be limited. First, meeting only a dozen or so times of year, they are unlikely to have the time to familiarize themselves sufficiently with the firm's operating and accounting practices to uncover and prevent mismanagement before it has gone too far. Moreover, they often rely on the same management for the information that may reveal their culpability. Second, managers also tend to control who serves on the board. Every year, in most firms, managers nominate a slate of directors to be elected at the annual shareholders' meeting. The nominating process, then, also acts to compromise the independence of outside directors. Directors might be reluctant to question and thereby lose the support of management.

Given the above limitations, one of the strongest incentives that outside directors have to monitor is to preserve their reputation capital and business relationships (see Fama and Jensen, 1983). Prior researchers have argued that the value of directors' reputations manifests itself in additional board seats and fees, stock, and options grants that accompany those appointments (see Yermak, 2004). Similarly loss of reputation manifests itself in the loss of board appointments (see Fich and Shivdasani, 2007). However, these incentives are not wholly consistent with the incentive to maximize shareholder wealth. For one thing, outside directors may be more concerned with their reputations for cooperating with management than as "watch dogs" for shareholders, i.e., directors can be

Journal of Corporate Finance, Vol. 16, No. 1 (February 2010): pg. 38-52. DOI. This article is (C) Elsevier and permission has been granted for this version to appear in e-Publications@Marquette. Elsevier does not grant permission for this article to be further copied/distributed or hosted elsewhere without the express permission from Elsevier. 
susceptible to cronyism. Specifically, cronyism can manifest itself as the exchange of board seats for awarding excessive compensation for the CEO or ignoring poor performance. Another thing is that, there are likely to be higher time costs associated with discovering mismanagement early; the longer mismanagement persists the more likely it will be revealed with a minimal amount of the director's time spent on discovery. Then, when there is clear and public evidence that managers are not acting in shareholders' interests, directors may have no choice but to act to discipline managers or they risk losing their reputation as independent monitors. However, this makes outside directors more of a mechanism of last resort rather than the proactive monitors that shareholders wish them to be. For example, boards tend to replace the CEO after a period of poor firm performance (see Weisbach, 1988) rather than remove the CEO before the damage has been done (see Jensen, 1993, for a more complete discussion of the failures of internal control systems).

Furthermore, since most board decisions are by a majority consensus, a single director relies on the support of others when questioning management (see Mace, 1971). Different directors will face different time costs and differing obligations to management which can create disagreements between directors about how to fulfill their monitoring obligation to shareholders.

Because of these tensions, board room conflicts can spill outside the confines of the board room and into the public press. Outside directors can resign when frustrated with a weak and ineffectual board, but may go further and publicly criticize management as a means of distancing themselves from a poorly performing firm. It is also likely that outside directors will publicize their reasons for resigning from the board when they are not leaving because of conflicts with management. Such statements can preserve their reputations for cooperating with management and reassure shareholders their leaving is not a sign of hidden trouble. Likewise, when outside directors resign publicly, but decline to provide a reason, the director may decide to let his or her silence speak for itself.

These resignations can have consequences for shareholders. Directors might offer a "busy" related reason for leaving a board when the firm is in trouble, rather than criticizing the firm, because they

Journal of Corporate Finance, Vol. 16, No. 1 (February 2010): pg. 38-52. DOI. This article is (C) Elsevier and permission has been granted for this version to appear in e-Publications@Marquette. Elsevier does not grant permission for this article to be further copied/distributed or hosted elsewhere without the express permission from Elsevier. 
seek to maintain their reputations as cooperative with management. If so, such resignations could be indicative of managerial entrenchment, leading to discipline from the external control market. Alternatively, if directors, truly leave because they are busy, such resignations can improve shareholder wealth by allowing for the appointment of a director who can spend more time on board activities.

Resignations accompanied by public criticism can put pressure on the remaining directors to improve firm performance. Or public dissension in the board room may suggest that the board will be more amenable to a takeover offer. Alternatively, these might be benign events. They may be the actions of a lone disgruntled director or indicative of a personality clash between the director and the CEO or other members of the board. Then again these resignations may be viewed negatively by the market but ultimately ineffectual in bringing about positive change. Worse yet the firm may lose the monitoring benefits of a good director allowing management to become even more entrenched. $\underline{2}$

In this study we investigate a sample of 52 outside director resignation announcements from 1990 to 2003. We compare our sample of public resignations to a random sample of 52 firms where outside directors leave the board "quietly," i.e., with no public announcement in the financial press. These samples allow us to investigate the circumstances around directors' decisions to publicize their resignation independent of the decision to leave the board. We find that half the time directors resign stating that they are busy and the other half of the time directors announce they are resigning because of uncooperative management or for some other problem with the firm that is likely to reflect conflict with management.

Directors who leave "quietly" are more likely to be professional directors, i.e., retirees, and significantly older-mid sixties-than directors who leave publicly. These directors are more likely to be at the end of their professional lives and less likely to feel compelled to publicly clarify their reasons for leaving the board as a means of preserving their reputation capital. Younger directors have more years left in their careers and hence more to lose from a damaged reputation. Directors who publicize their resignations are around eight to ten years younger than those who leave "quietly."

Journal of Corporate Finance, Vol. 16, No. 1 (February 2010): pg. 38-52. DOI. This article is (C) Elsevier and permission has been granted for this version to appear in e-Publications@Marquette. Elsevier does not grant permission for this article to be further copied/distributed or hosted elsewhere without the express permission from Elsevier. 
Directors who resign for "busy" related reasons are more likely to be active professionals. The firms that these directors resign from have some weakness in performance in the period prior to the resignation suggesting that changes in firm performance is putting greater demands on directors. We do not find any evidence that either the CEO or the directors are excessively compensated in these firms or that there is upward manipulation of earnings. Thus we conclude that these resignations are not attempts by directors to protect management or evidence of cronyism.

Directors are more likely to resign for "conflict" related reasons when the board is weak. These boards are less independent, smaller and dominated by a CEO who is also chairman of the board. Consistent with their desire to publicly distance themselves from poorly performing firms, we find that these directors are more likely to resign from firms with recent declines in operating performance and sales. They are more likely to be finance professionals and been a member of the audit and/or compensation committees. Not surprisingly, "conflict" firms have an increase in accounting accruals, indicating that management may be manipulating earnings to mask poor performance. Given their financial backgrounds and/or their membership on the audit committee, it is likely to be more embarrassing to have served on the board of a company with deteriorating financial performance and questionable accounting practices.

Finally, we find evidence that public criticism of the firm pressures the board to make changes. In the six months following these announcements we find significantly positive market adjusted stock price performance and a higher frequency of internal management changes. The overall weight of the evidence suggests that outside directors resign for "conflict" related reasons in poorly performing firms with weak boards, perhaps to protect their own reputation, but that such resignations ultimately are effective in improving firm performance.

The findings of our study contribute to the vast literature on board functioning. While there have been previous studies examining changes in the board which have investigated the turnover of insiders (see Hermalin and Weisbach, 1988); the addition of outsiders (Gilson,

Journal of Corporate Finance, Vol. 16, No. 1 (February 2010): pg. 38-52. DOI. This article is (C) Elsevier and permission has been granted for this version to appear in e-Publications@Marquette. Elsevier does not grant permission for this article to be further copied/distributed or hosted elsewhere without the express permission from Elsevier. 
1990 and Rosenstein and Wyatt, 1990); outside director turnover simultaneously with a forced CEO turnover (see Farrell and Whidbee, $\underline{2000}$ ), the resignation of both inside and outside directors (see Fields and Gupta, 2004), the resignations of outsiders prior to poor performance (see Brown and Maloney, 1999), and resignations of outside directors following disputes (see Agrawal and Chen, 2008), our study is designed to specifically investigate the motivations of outside directors' decision to publicly criticize the firm as they leave vis-à-vis more benign departures. This study shows that self interest is likely to motivate directors to make their disagreements public but can also be a mechanism for disciplining managers when the board is weak.

The rest of the paper is organized as follows. Section 2 describes the sample and data. Section 3 documents the types of resignation reasons given and the stock price reaction to these announcements. Section 4 investigates the characteristics of resigning outside directors and the boards that they resign from. Sections 5 and 6 provide the results of univariate tests of the differences in corporate governance characteristics and firm performance for different types of resignation announcements. Section 7 reports the results of a multivariate regression results for the director's choice to publicize his or her resignation. Section 8 documents changes in stock price performance and firm activity after the resignation announcements. Section 9 concludes the paper with suggestions for future research.

\section{Sample and data}

We construct a sample of director resignations by searching both the Wall St. Journal and Lexis/Nexis full text data base from 1990 to 2003 using various forms of the search words "director" and "resign". This search produced 464 articles of 735 director resignations. Using these articles and proxy statements to confirm that the director was an outsider, we construct a sample of 290 outside director resignations. We classify outsiders as those who are not employees, former employees or related to any employees of the firm. Outside directors are also those that have no obvious affiliation with the firm or management, such as the firm's external legal counsel, banker, or a director that has received consulting fees, as disclosed in the firm's proxy statement. This sample excludes directors who did not

Journal of Corporate Finance, Vol. 16, No. 1 (February 2010): pg. 38-52. DOI. This article is (C) Elsevier and permission has been granted for this version to appear in e-Publications@Marquette. Elsevier does not grant permission for this article to be further copied/distributed or hosted elsewhere without the express permission from Elsevier. 
resign but simply let their term expire and/or resignations that were not announced in the press. We also exclude events that are contaminated with other announcements.

Fields and Gupta (2004) also construct a sample using a key word search of Lexis-Nexis and report a sample of 133 "outsider" director resignations between 1990 and 2000. They define "outsider" directors as non-employee directors who are not also former employees of the firm, relatives of the firm's employees, bankers, accountants, consultants, or attorneys of the firm. Thus our initial sample of 290 outside director resignations is comparable to that of other studies and is likely to represent most if not all announcements.

An alternative source of director resignations announcements are Form 8-Ks. Agrawal and Chen (2008) use 8-Ks to construct a sample of 168 director resignations from 1995 to 2006. Under current SEC rules firms are required to disclose whether a director resigned because a disagreement with management and within 4 days of the event. However, these rules were not enacted until 2004. ${ }^{3}$ Not surprisingly, the number of resignations for disputes with management in the Agrawal and Chen (2008) sample more than double after 2004 and over $42 \%$ of the observations in their sample occur in 2005 and 2006. The rules governing Form $8-\mathrm{K}$ filings during our sample period require that they be filed between 5 and 15 days after the occurrence of certain material events, such as bankruptcy filings, auditor change, change in control, and a director resignation. Firms are not required to disclose if a director resigned because of a conflict with management. Prior studies examining the information content of 8-Ks using a sample period prior to 2004 have found that these forms did not provide timely information for director resignations (see Carter and Soo, 1999). Since stock price reactions to the resignation, as well as the reason given, are important measures in our study, we focus on constructing a sample created from announcements rather than less timely and informative SEC filings.

From our initial sample of announcements of outside directors, we require firms to have sufficient data on Compustat so that we can investigate changes in firm performance related to director resignations. This restriction reduces our sample to seventy-eight firms. We lose an additional fourteen firms because of insufficient data been granted for this version to appear in e-Publications@Marquette. Elsevier does not grant permission for this article to be further copied/distributed or hosted elsewhere without the express permission from Elsevier 
in CRSP to calculate stock price reactions to the resignation announcement. Finally we lose twelve more firms because of missing information on corporate governance characteristics available in proxy statements and $10-\mathrm{K}$ filings for the year prior to the resignation year. Our final sample consists of 69 director resignations for 52 separate announcements for 49 separate firms.

We also create a comparison sample of instances where outside directors leave the firm "quietly." We initially identify firms that are both on Standard and Poor's Execucomp and the IRRC Directors data base spanning the 1996-2004 period yielding 2980 firms and 25,622 unique directors for a total of 14,563 firm years. We identify 1326 firm years where an outside director left the board "quietly", i.e., is not included in our announcement sample. Outside directors are those that are identified as independent directors by the IRRC database. Our requirement that firms have sufficient data on CRSP and Compustat eliminates another 123 and 195 firm-years, respectively. Lastly, we require that firms have data on blockholdings as provided through the WRDS data base and another 453 firm-years are eliminated. The final sample of outside director resignations consists of 555 firms. From this sample of 555 firms we randomly pick 52 firms. We use the smaller sample to facilitate the hand collection of data, for example, the classification of director's primary occupations and firm events that occur after the resignation. However, by reducing our sample size we reduce the power of our tests. We also do not make inferences about specific differences in variables across the different types of resignations for the general population of outside director resignations.

Table 1, Panel A, reports the distribution over our sample period of the number of resignation announcements from both the initial sample and our final sample. This table shows that, while there is variation in the frequency of resignation announcements from year to year, there is no obvious clustering over time or trends in the frequency of resignations for either the larger or reduced sample. The number of directors resigning at once range from 1 to 4 ; the average is 1.5 and the median is 1 .

Table 1, Panel B, reports the distribution over our sample period of the number of "quiet" resignations from both the initial sample and our final sample. Again, there appears to be no obvious clustering over

Journal of Corporate Finance, Vol. 16, No. 1 (February 2010): pg. 38-52. DOI. This article is (c) Elsevier and permission has been granted for this version to appear in e-Publications@Marquette. Elsevier does not grant permission for this article to be further copied/distributed or hosted elsewhere without the express permission from Elsevier. 
time in the number resignations. Because of the availability of data on IRRC (begins in 1996) and WRDS Blockholder data base (ends in 2001), we have no observations in this sample prior to 1996 (the announcement sample has 19 firms) or after 2001 (the announcement sample has 11 firms). Because of the small size of the announcement sample, we are reluctant to eliminate firms in this sample to match the time frame of the comparison sample. However, we test whether there are any statistically significant differences in the variables used in our tests for the announcement sample pre- and post 1995 and pre- and post 2001 and find none.

Our sample is not constructed to identify factors that predict the likelihood of a public resignation, i.e., it is not random. However, the results reported in Table 1 suggest that public resignations are relatively infrequent events. The number of outside resignation announcements as a percentage of all outside director turnovers meeting our data requirements ranges between 0 and $7.55 \%$. "Conflict" related resignations account for roughly half of these public resignations and thus are even more infrequent. Yet, most actions that discipline management occur infrequently. Faleye (2007) using a sample from 1995 to 2002 documents 219 forced CEO turnovers among 1483 CEO replacements suggesting that CEO turnovers that are discipline related occur $14.77 \%$ of the time. For this same sample, Faleye (2007) documents 102 proxy contests in a sample of 11,464 firm years (or annual elections of the board) suggesting that elections are contested or used to discipline managers less than $1 \%$ of the time. Yet, nonetheless proxy contests and forced CEO turnovers are long recognized events that are associated with increases in shareholder wealth (see Dodd and Warner, 1983 and Weisbach, 1988). We also document improvements in firm performance following the resignations of outside directors who publicly criticize management. Hence, while infrequent, these resignations are another important mechanism for disciplining management and improving shareholder wealth.

Journal of Corporate Finance, Vol. 16, No. 1 (February 2010): pg. 38-52. DOI. This article is @ Elsevier and permission has been granted for this version to appear in e-Publications@Marquette. Elsevier does not grant permission for this article to be further copied/distributed or hosted elsewhere without the express permission from Elsevier. 


\section{Reasons given in resignation announcement and stock price reaction}

The first place we look in examining directors' motivations for publicly resigning is the reason he or she gives in the announcement. Table 2 shows the different types of reasons given. The most common reason given is other professional commitments (33\%), followed by uncooperative management (23\%). Less frequently, resignations also occur in the wake of some type of regulatory investigation, i.e., an SEC investigation of the firm's accounting practices, (6\%), or company poor performance (4\%). We also find two incidences of directors announcing that they are resigning in connection with a reduction of their ownership stake. Because directors are likely to have better information than other investors (see Seyhun, 1992 and Noe, 1997), we infer that a reduction in an investment in the firm is likely to be a negative signal. We also find that health (4\%), personal, family commitments $(6 \%)$ or other time commitments $(8 \%)$ are given as reasons. Finally, about $13 \%$ of the time no reason is given in the announcement.

We group these reasons into two categories-(1) "Conflict" related reasons: uncooperative management; regulatory investigation or shareholder lawsuit; ownership stake reduction; company poor performance; and unknown; and (2) "Busy" related reasons: health, personal, family commitments or other time commitments. Prior to the passage of new SEC rule in 2004, companies were not required to disclose director's resignation letters; hence many directors followed a policy of "what happens in the board room stays in the boardroom." 4 We find that the decision to announce a resignation without providing a reason is viewed negatively by the market; the average two day cumulative abnormal return is $-1 \%$ (median $=-0.05 \%$ ). Therefore, we group resignation announcements that do not provide a reason with "conflict" related reasons. To the extent that the reasons are really benign and not "conflict" related we bias our results against finding a difference between the two types of announcements. Our sample contains 26 announcements for "conflict" related reasons and 26 announcements for "busy" related reasons (it is coincidental that the sample is evenly split between the two categories). While not reported in the tables, we find no statistical relation between year and

Journal of Corporate Finance, Vol. 16, No. 1 (February 2010): pg. 38-52. DOI. This article is @ Elsevier and permission has been granted for this version to appear in e-Publications@Marquette. Elsevier does not grant permission for this article to be further copied/distributed or hosted elsewhere without the express permission from Elsevier. 
type of reason announced. We use the "conflict" related reasons and "busy" related reasons categories along with directors who leave "quietly" in the remainder of our tests. Comparing characteristics of firms across the three types of resignations allows us to test the motivations and consequences of public statements accompanied by a resignation, other than the resignation itself.

Table 3 reports the stock price reaction to the resignation announcement depending on the reason given. For "conflict" related reasons the one day abnormal return is $-1.17 \%$ and the 3 -day cumulative abnormal return is $-3.10 \%$-both are statistically significant at the $5 \%$ level. For "busy" related reasons both the one day and the 3-day cumulative abnormal returns are positive but not statistically different from zero. However, for a larger sample of 109 resignation announcements for which we have sufficient return data the three day cumulative abnormal return for announcements for resignations for "busy" related reasons it is $+1.64 \%$ and statistically significant at the $10 \%$ level. Fich and Shivdasani (2006) find that the market reacts positively when directors who they define as busy (three or more directorships) leave the board and conclude that busy directors are detrimental to firm value. Similarly, we find that the market reacts positively when directors leave the board explicitly stating that they are busy. This evidence also suggests that "busy" related reasons are not given to protect poorly performing managers.

\section{Characteristics of outside directors resigning}

In this section we investigate the characteristics of directors who resign for different reasons. We use four categories for our tests of types of directors. First, we group executives who are retired from their primary profession as "professional" directors. Because these directors are retired the time cost associated with monitoring is likely to be less, which, in turn, is likely to make them better monitors (see Brickley et al., 1994). It is also likely that these directors are less likely to resign for "busy" related reasons. Second, we group directors who are accountants, commercial bankers, corporate finance officers, investment professionals, individual investors, or directors who are retired from these professions as "finance professionals" (retired finance professionals are excluded from the "professional directors"

Journal of Corporate Finance, Vol. 16, No. 1 (February 2010): pg. 38-52. DOI. This article is (c) Elsevier and permission has been granted for this version to appear in e-Publications@Marquette. Elsevier does not grant permission for this article to be further copied/distributed or hosted elsewhere without the express permission from Elsevier. 
category). Agrawal and Chadha (2005) provide evidence that independent directors with financial expertise are valuable in providing oversight of a firm's financial reporting practices. Third, we group together all other executives. Finally, all other types of outside directors are classified as "other". This last category includes academics, past or current government officials or members of public policy commissions, philanthropists, and members of other professions, i.e., medical.

We also collect data on whether outside directors are on the audit, compensation or nominating committee. Prior researchers have found that outside directors on the audit committee can have an influence on the firm's accounting policies (see Xie et al., 2003). We collect data on director's stock ownership. We also collect data on CEO and director tenure and measure the number of years that the director and CEO have served together. Further we create a variable, (CEO tenure/Director tenure), as a measure of the CEO's relative power over the director; a CEO who has been at the firm longer than a director may have more influence over board decisions. All of our data is collected using the last proxy statement that is issued prior to the resignation announcement date or the year prior to the resignation year for the comparison sample using the IRRC data base.

Table 4 reports our results. We create three sub-samples of firms based on the reason given for the resignation- "conflict," "busy," and "non-public". We test whether there are differences between outside directors who resign and those who stay within each subsample as well as differences in resigning director characteristics across the three different sub-samples. We use the myriad of the test results reported in Table 4 to develop a profile of the archetypal director who resigns for each of the three reasons described below. For individual test results, we refer the reader to Table 4.

Outside directors resigning for "conflict" related reasons are active professionals and more likely to have financial backgrounds compared to directors resigning for other reasons. They are in their mid-fifties suggesting that they still have many years left in their careers. In the context of poor firm financial performance, these directors have a strong incentive to distance themselves from the firm to preserve their reputations as financial experts. They are also more

Journal of Corporate Finance, Vol. 16, No. 1 (February 2010): pg. 38-52. DOI. This article is @ Elsevier and permission has been granted for this version to appear in e-Publications@Marquette. Elsevier does not grant permission for this article to be further copied/distributed or hosted elsewhere without the express permission from Elsevier. 
likely to be on the audit and/or compensation committees. Their financial expertise coupled with committee membership suggests that they also are likely to have both greater knowledge and concern about either the company's accounting practices (external reporting or internal controls) and/or the company's financial results. Finally, they have higher stock ownership. Their higher ownership stake provides another reason to be concerned about the financial performance of the firm.

Directors who resign for "busy" related reasons are also in their mid-fifties and still active professionals and busy. They are less likely to be on the compensation committee. This suggests that these directors are less likely to have conflicts with the CEO and CEO compensation. It may also be the case that they were not assigned committee membership because they were busy. Finally, they have a relatively short tenure compared to the CEO. It is possible that the director is concerned that a dominant CEO will be problematic in the future and decides to leave the board, citing, he or she is too "busy." Alternatively, a dominant CEO may put greater demands on directors causing some of them to leave because they are too "busy."

Directors who leave "quietly" are more likely to be professional directors. These directors are around 65 years old suggesting that they are retiring, entirely, from professional life as well as the board. Unlike younger outside directors who resign publicly to protect future opportunities, if directors who leave "quietly" are retiring, they will not be compelled to explain their exit. Additional findings confirm that they are retiring entirely from professional life. They have relatively longer tenures and have served more years with the CEO, indicating retirement after a lengthy period of service on the board. They are less likely to be on either the audit or compensation committee. As directors approach retirement, the board may remove them from committees as part of succession planning.

\section{Corporate governance characteristics}

In this section, we investigate the corporate governance characteristics of firms where directors resign for different reasons. We test for differences in board characteristics, CEO compensation, and

Journal of Corporate Finance, Vol. 16, No. 1 (February 2010): pg. 38-52. DOI. This article is (C) Elsevier and permission has been granted for this version to appear in e-Publications@Marquette. Elsevier does not grant permission for this article to be further copied/distributed or hosted elsewhere without the express permission from Elsevier 
outside ownership across the three sub-samples of firms with different types of resignations-"conflict," "busy," and "nonpublic."

Table 5 reports the frequency of different types of directors and their committee membership. Firms with outside directors resigning for both "conflict" and "busy" related reasons are less likely to have professional directors serving on the board. There are two explanations for this finding. Firms that are likely to have directors leaving "quietly" are more likely to be firms with director retirements. As a result, these firms are likely to have more professional retirees serving on their boards to begin with. Alternatively, and more importantly, firms with less professional retirees may be less effective in fulfilling their monitoring function because of greater time constraints faced by most directors on the board. The expectation of time spent on board matters might increase for each director serving on the board without retired professionals able to shoulder more. Hence, directors may be more inclined to resign, stating they are "too busy" to serve on these boards. Further, boards made up of professionals who have less time to spend on board matters may fail to adequately monitor managers and become dysfunctional. Hence, directors may be more inclined to resign publicly criticizing the firm. Our results on firm performance support the second alternative.

Committee membership also differs across the three types of resignations. Table 5 shows that for firms with public resignations, the audit committees have proportionately more finance professionals. However, firms with "conflict" related resignations have more insiders on this committee where finance professionals are more likely to come in conflict with management about accounting policies and the financial performance of the firm. The composition of the compensation committee provides additional evidence of board dysfunction for these firms. For "conflict" firms, this committee has proportionately less professional directors, who by virtue of being closer to retirement are less beholden to management, and more insiders, who have obvious conflicts of interests in serving on this committee. This committee composition is likely to be another manifestation of a weaker board structure as discussed below.

Table 6, Panel A, reports other board characteristics. The percentage of outside directors on the board and board size are

Journal of Corporate Finance, Vol. 16, No. 1 (February 2010): pg. 38-52. DOI. This article is (C) Elsevier and permission has been granted for this version to appear in e-Publications@Marquette. Elsevier does not grant permission for this article to be further copied/distributed or hosted elsewhere without the express permission from Elsevier. 
smaller for firms with "conflict" related resignations. Prior researchers (see Brickley et al., 1997 and Goyal and Park, 2002) have found evidence that suggests that CEO's who are also Chairman of the Board are more likely to have greater control over the board so we also examine the frequency with which the CEO is also Chairman of the Board across the three types of resignations. We find that the CEO is more likely to be the chairman of the board for firms where outside directors have resigned for "conflict" related reasons. An outside director may be pushed to resign in protest when conflicts cannot be resolved internally with a CEO who dominates a smaller, less independent, board's deliberations.

Additionally, we investigate whether there are differences in total stock ownership held by outside directors and director compensation. Higher stock ownership is likely to increase incentives for outside directors to monitor and may counter other weak board characteristics. Low director compensation could be a source of disagreement between directors and management while, higher compensation (and stock ownership acquired through grants) could be indications of cronyism (see Brick et al., 2006). However, as Table 6 , Panel A shows, we find no statistically significant differences in these variables across firms with different resignation types.

We also report the percentage of directors who resign for each resignation announcement. Table 6 , Panel A, shows that, roughly, when an outside director resigns for "conflict" related reasons another outside director also resigns with him or her suggesting that conflicts with management are unlikely to be isolated personal disputes. We also find that an insider is less likely to resign when an outside director resigns for "busy" related reasons. Changes in business conditions for the firm may increase demands on already "busy" directors but also may increase advancement opportunities for insiders. In fact, as discussed later, we do find an increase in management changes for these firms.

Table 6, Panel B, reports various characteristics of the CEOage, tenure, total compensation, incentive compensation, and ownership. We scale total compensation by both sales and operating income to control for compensation differences related to size and operating performance. We find no evidence that the CEO of firms with 
"conflict" resignations is overpaid. We also never find that a director gives excessive CEO compensation as a reason for resigning (we find one case in the larger sample of 735 resignations but this announcement did not make it into our final sample). Since compensation contracts are negotiated in advance, they are less likely later to trigger a director's resignation ex post. We also find that CEOs of firms with "conflict" resignations have more stock ownership. CEO ownership may be another dimension of CEO domination of the board for these firms as discussed above.

Finally, we collect data on outside blockholders. The presence of blockholders can put added pressure on firms to perform well (see Dahya et al., 2008, Denis and Serrano, 1996 and Peck, 1996). It is likely that the absence of a large blockholder is another dimension of poor corporate governance for firms with "conflict" related resignations. However, Table 6 , Panel $C$, shows that the presence of an outside blockholders in firms with resignations for "conflict" related reasons is at least as strong as in the other firms. Hence, we conclude that the absence of a large blockholder does not explain directors' decisions to leave the firm and publicly criticize management.

\section{Firm characteristics}

In this section we test for differences in various measures of firm performance between firms with the three types of resignations. We exclude fiscal year end data from the year of the resignation announcement or the "event" year to avoid contaminating our results with changes in firm performance that occur after the director has resigned. Resignation announcements can occur throughout the fiscal year making it difficult to determine within that year the causal relation between fiscal year results and the director resignation. ${ }^{5}$ For our comparison sample we use the three fiscal years prior to the resignation year. Table 6 , Panel $D$, reports the results of these tests.

Our results show that firms with public resignations are larger than firms where directors leave quietly. Larger firms are likely to be more closely followed by the financial press and hence report directors' reasons for resigning. Hence, we control for size in our multivariate tests. We also find differences in that the beta of firms between the

Journal of Corporate Finance, Vol. 16, No. 1 (February 2010): pg. 38-52. DOI. This article is (C Elsevier and permission has been granted for this version to appear in e-Publications@Marquette. Elsevier does not grant permission for this article to be further copied/distributed or hosted elsewhere without the express permission from Elsevier. 
three sub-samples and control for beta in all of our subsequent tests. Finally we collect data on the frequency of two-digit SIC codes of the two types of firms and find over thirty codes are represented with no more than five observations represented by any one code in any one resignation category (and only one with five). We conclude that industry classification is not related to the type of resignation announcement.

We also investigate whether firm performance explains the type of resignation. We hypothesize that changes in performance are more likely to be triggers for resignations than levels alone. For example, suppose we have two firms with the same level of performance. One of these is a more profitable firm that had a decline in profits, while the other was a less profitable firm that improved. We predict that the former firm is more likely to have a director that resigns for a "conflict" related reason.

We collect data on changes in sales and operating income as two key measures of performance. Table 6 , Panel D, shows that after a period of increases in sales and operating performance, both decline for firms with "conflict" related resignation during the year prior to the resignation. Such conditions can lead to conflict in the boardroom. For firms with "busy" related resignations, firm performance remains relatively stable while for firm with "quiet" resignations, firm performance improves.

Table 6, Panel D, also reports the results for other measures of performance-average annual percentage sales growth in the three years prior, operating margins (EBITDA/Sales), and percentage of firms reporting a loss, and market adjusted stock price performance six and twelve months prior to the resignation year. The overall weight of the evidence on all of these performance measures show that firms with resignation announcement for "conflict" related reasons have poorer performance than firms with either resignation announcements for "busy" related reasons or firms with "quiet" resignations. We also find that firms with resignations for "busy" related reasons have weaker performance than firms with "quiet" resignations. Weak firm performance can create greater demands on directors.

Journal of Corporate Finance, Vol. 16, No. 1 (February 2010): pg. 38-52. DOI. This article is (C) Elsevier and permission has been granted for this version to appear in e-Publications@Marquette. Elsevier does not grant permission for this article to be further copied/distributed or hosted elsewhere without the express permission from Elsevier. 
Finally, we investigate whether there are differences between the three types of firms in changes in accounting accruals. Table 6, Panel $D$, shows that firms with "conflict" related resignation announcements are more likely to have greater positive changes in accruals. This indicates that management may be manipulating accruals to mask poor performance creating another source of conflict between directors and management. $\underline{6}$

\section{Likelihood of resigning for "conflict" related reasons}

Table 7 reports the results of a logit regression for the likelihood that an outside director resigns publicly for "conflict" or "busy" related reasons or leaves "quietly." We include variables that identify who these directors are and what types of firms they resign from. We report these multivariate results to confirm our earlier findings.

The results in Table 7 show that an outside director is more likely to resign for "conflict" related reasons when the director is a financial professional and a member of the audit or compensation committee. Directors are also more likely to resign in protest when operating performance is lower and accounting accruals are higher. These findings are consistent with our earlier results.

Our results also show that directors who resign for "busy" related reasons are more likely to resign from firms where the CEO has greater tenure than they do. As discussed earlier these could be indications of either a greater demand on their time or cronyism. The regression results are not consistent with findings of cronyism; directors are more likely to resign for "busy" related reasons as CEO compensation falls. In addition, the results also show that these resignations are more likely to occur for firms with smaller, more independent boards, where the CEO is less likely to be chairman of board. These findings are not consistent with cronyism.

Table 7 also shows that outside directors are more likely to resign for "busy" related reasons when sales growth and operating performance are low, but there are recent increases in operating profits. It appears that while these firms that have some softening in

Journal of Corporate Finance, Vol. 16, No. 1 (February 2010): pg. 38-52. DOI. This article is (c) Elsevier and permission has been granted for this version to appear in e-Publications@Marquette. Elsevier does not grant permission for this article to be further copied/distributed or hosted elsewhere without the express permission from Elsevier. 
their financial performance, they also have some indication of future improvement. Implementing and monitoring plans for improved performance may put greater demands on director's time leading to more decisions to leave for "busy" related reasons.

Table 7 also shows that, consistent with our earlier findings, directors are more likely to leave "quietly" when they are older professional directors and have not served on either the audit or compensation committee. Directors are also more likely to leave "quietly" as the CEO compensation increases and firm performance is higher and has recently been improving. While the higher level CEO compensation might be an indication of entrenchment, this interpretation is tempered by the higher level of firm financial performance. Finally, in contrast to firms where directors leave for "conflict" related reasons, the results in Table 7 show, that in firms where directors leave "quietly," the change in total accruals are negative suggesting there is no attempt to manipulate accruals to improve financial results.

\section{Changes after the resignation}

In this section we investigate changes in the frequency of firm events and shareholder returns after the resignation. Table 8 , Panel A reports market adjusted shareholder returns for six and twelve months following the announcement. Seven firms have less than six months of return data. For the months that data is no longer available for these firms, their return is replaced with the return on the S\&P 500 so that the market adjusted performance is zero for these months. All seven firms that were delisted have resignation announcements that are "conflict" related. Two firms filed for Chapter 11 . One firm was delisted and litigated by the SEC for overstatement of revenue. Another firm was delisted for poor financial performance and at the time of delisting was likely to be sold. Two firms were taken over.

Table 8, Panel A shows that in the six months following resignation announcements for "conflict" related reasons both the average and median market adjusted performance is positive and statistically significant. None of the other returns reported are statistically significant. These findings support the notion that resignations accompanied by public criticism of management can lead

Journal of Corporate Finance, Vol. 16, No. 1 (February 2010): pg. 38-52. DOI. This article is (C) Elsevier and permission has been granted for this version to appear in e-Publications@Marquette. Elsevier does not grant permission for this article to be further copied/distributed or hosted elsewhere without the express permission from Elsevier. 
to improvements in shareholder wealth. It is also possible that the improved share price performance for firms with "conflict" related resignations represents a reversion to the mean after a period of poor share price performance as documented in Table 6, Panel D.

We collect data on the frequency of events that occur after the resignation to further understand the changes that lead to the improvements in shareholder wealth. Of the seven firms that were delisted as described above, the two with takeovers will increase shareholder wealth with the offer of a takeover premium. The reasons for the delisting of the other five firms-bankruptcy and SEC litigation-are likely to be associated with a decrease shareholder wealth. In Panel B of Table 8 we report the frequency of events other than those that led to the delisting of the seven firms above-focusing on management changes, asset restructuring and control related events. We also report "other" types of events, such as SEC investigations and miscellaneous lawsuits. However, the frequency of these events is too low to be meaningful.

We find that there is a higher frequency of internal management changes, such as changes in the CEO or other top executives for firms with "conflict" related resignations. This suggests that remaining board members feel pressure to "shake up" management after a director leaves while publicly criticizing the firm. There is also an increase in the frequency of the adoption of control defenses after directors leave for "conflict" reason. Hence, some firms may become further entrenched.

We use a multivariate regression analysis to sort out the various scenarios for both share price performance and the likelihood of an event. We include both the reasons given by the resigning director, resigning director characteristics, the occurrence of other events, board characteristics, and performance measures in these regressions. We also include a dummy variable indicating whether the firm was delisted. Our results are reported in Table 9. The six month market adjusted return is statistically significantly higher when a "conflict" related reason is given in the resignation announcement after controlling for other variables. Table 9 also shows that the likelihood of an internal control change increases with "conflict" related resignations. Of course, it is possible that outside directors resign 
because they anticipate these changes. It is also possible that the dissenting director was preventing the board from moving forward with management changes. Yet, no matter what the director's or the boards' motivations, the public criticism is likely to create added pressure and in turn increase the likelihood of the board acting.

We also find that internal management changes increase with resignations for "busy" related reasons. Changes in executive positions can reflect an increase in the "busyness" for the firm. Our results also show internal control change events are less likely when the resigning outside director was a member of the compensation committee. This may reflect disagreements about compensation, executive changes, and, ultimately entrenchment. Finally, Table 9 also reports the results of regression of the likelihood of a control defense and shows that the parameter estimate for "conflict" related reason is statistically insignificant. Thus our findings show that a director resigning in protest does not increase managerial entrenchment.

\section{Conclusion}

In this study we investigate a sample of outside director resignation announcements from 1990 to 2003. We also investigate a comparison sample of firms where an outside director leaves "quietly," i.e., with no public announcement. Outside directors who resign in protest are more likely to be finance professionals and so do from firms with weak boards and a recent decline in performance. Directors who resign claiming they are "too busy" are active professionals who are likely, in fact, to be busy. We find no evidence that these directors claim they are busy to protect entrenched management. Non public resignations appear to be ordinary retirements. We conclude that directors resign publicly to protect their professional reputations. Yet, resignations for "conflict" related reasons are followed with a higher frequency of internal management changes along with positive market adjusted returns. The overall weight of the evidence suggests that while directors self interest might prompt public criticism of the firm it also forces the board to act to improve shareholder wealth.

Thus this study examines a sample where monitoring has failed-directors resign when they feel they can no longer monitor the CEO. Our findings provide additional insight into the forces that create

Journal of Corporate Finance, Vol. 16, No. 1 (February 2010): pg. 38-52. DOI. This article is (C) Elsevier and permission has been granted for this version to appear in e-Publications@Marquette. Elsevier does not grant permission for this article to be further copied/distributed or hosted elsewhere without the express permission from Elsevier. 
an ineffective board. We find that directors resign publicly from firms with less professional directors on the board from firms that are struggling with performance. This suggests the importance of populating boards with professional directors. Future study of these directors is needed to clarify their role in board functioning and its impact on firm value.

Our findings also highlight the use of public statements criticizing management as another corporate governance mechanism available to pressure management to act in shareholders' interests. Another example is hedge funds that make critical statements of management in the press to both pressure management and to signal to other hedge funds to buy shares to provide additional shareholder support for either internal change or a takeover. $\stackrel{7}{ }$ Other examples of the use of the press as a corporate governance mechanism warrant further identification and study.

\section{Notes}

- $\diamond$ We wish to thank Tina Yang, the referee, for many helpful comments and suggestions. Useful comments and suggestions were also received on an earlier version of this paper at the Midwest Finance Association Meetings Spring 2007.

- ${ }^{*}$ Corresponding author. Tel.: +1 414288 1446; fax: +1 4142885756.

- E-mail addresses: michael.dewally@marquette.edu (M. Dewally), sarah.peck@marquette.edu (S.W. Peck).

- 1 Tel.: +1 414288 1442; fax: +1 4142885756.

- 2 We are grateful to the referee for suggesting this alternative hypothesis.

- 3 In August 2004, the SEC made a final rule change to 8-K filings (17 CFR PARTS 228, 229, 230, 239, 240 and 249) in item 5.02 parts (a)-(b). These changes required disclosure of director resignations because of disagreement with management. These changes also shortened the time period of filing to 4 days within the triggering event. These

Journal of Corporate Finance, Vol. 16, No. 1 (February 2010): pg. 38-52. DOI. This article is (C) Elsevier and permission has been granted for this version to appear in e-Publications@Marquette. Elsevier does not grant permission for this article to be further copied/distributed or hosted elsewhere without the express permission from Elsevier. 
actions by the SEC speak to the importance of these events to shareholders.

- 4 "More Directors Are Breaching the Boardroom Wall of Silence," Phyllis Plitch, www.CareerJournal.com, from The Wall Street Journal Online.

- 5 Quarterly financial results using expectations models that adjust for both seasonal as well as prior performance would provide more timely information about firm performance and a better test of the relation between resignations and firm performance. However, the data requirements for these tests would reduce our already small sample. Yet, to the extent that we have less precise data, the power of our tests are reduced and biased against finding a relation.

- 6Admittedly, there are better methodologies available for detecting earnings manipulation than changes in total accruals alone (see Dechow et al., 1995). These methodologies are designed to control for both the firm's "normal" accrual generating process as well as changes in non-discretionary accruals that are performance related. However, these methodologies have greater data requirements that would further reduce our already small sample. For example, the data requirements for the Jones (1991) model would reduce our announcement sample by $50 \%$. However, we control for changes in performance in our multivariate tests of the relation between accrual changes and the likelihood of resigning for different reasons. This provides some control, albeit a crude one, for accrual changes related to performance.

- 7 See "Airing a CEO's laundry," Pierre Paulden, Institutional Investor, New York: Jun 2006. pg. 1. 
NOT THE PUBLISHED VERSION; this is the author's final, peer-reviewed manuscript. The published version may be accessed by following the link in the citation at the bottom of the page.

\section{References}

Agrawal, A., Chadha, S., 2005. Corporate governance and accounting scandals. Journal of Law and Economics 48, 371-406.

Agrawal, A., Chen, M.A., 2008. Boardroom brawls: an empirical analysis of disputes involving directors. Working Paper.

Brick, I.E., Palmon, O., Wald, J.K., 2006. CEO compensation, director compensation, and firm performance: evidence of cronyism? Journal of Corporate Finance 12, 403-423.

Brickley, J.A., Coles, J.L., Terry, R.L., 1994. Outside directors and the adoption of poison pills. Journal of Financial Economics 35, 371-390.

Brickley, J.A., Coles, J.L., Jarrell, G., 1997. Leadership structure: separating the CEO and chairman of the board. Journal of Corporate Finance 3, 189-220.

Brown, W.O., Maloney, M.T., 1999. Exit, voice, and the role of corporate directors: evidence from acquisition performance. Working Paper.

Carter, M.E., Soo, B.S., 1999. The relevance of 8-K form reports. Journal of Accounting Research 37, 119-132.

Dahya, J., Dimitrov, O., McConnell, J.J., 2008. Dominant shareholders, corporate boards, and corporate value: a cross-country analysis. Journal of Financial Economics 87, 73-100.

Dechow, P.M., Sloan, R.G., Sweeney, A.P., 1995. Detecting earnings management. Accounting Review 70, 193-225.

Denis, D.J., Serrano, J.M., 1996. Active investors and management turnover following unsuccessful control contests. Journal of Financial Economics $40,239-266$.

Dodd, P., Warner, J.B., 1983. On corporate governance: a study of proxy contests. Journal of Financial Economics 11, 401-438.

Faleye, O., 2007. Classified boards, firm value, and managerial entrenchment. Journal of Financial Economics 83, 501-529.

Journal of Corporate Finance, Vol. 16, No. 1 (February 2010): pg. 38-52. DOI. This article is @ Elsevier and permission has been granted for this version to appear in e-Publications@Marquette. Elsevier does not grant permission for this article to be further copied/distributed or hosted elsewhere without the express permission from Elsevier. 
NOT THE PUBLISHED VERSION; this is the author's final, peer-reviewed manuscript. The published version may be accessed by following the link in the citation at the bottom of the page.

Fama, E., Jensen, M.J., 1983. Separation of ownership and control. Journal of Law and Economics 25, 301-325.

Farrell, K.A., Whidbee, D.A., 2000. The consequences of forced CEO succession for outside directors. Journal of Business 73, 597-627.

Fields, L.P., Gupta, M., 2004. Board independence and corporate governance: evidence from director resignations. Working Paper.

Fich, E.M., Shivdasani, A., 2006. Are busy boards effective monitors? Journal of Finance $61,689-724$

Fich, E.M., Shivdasani, A., 2007. Financial fraud, director reputation, and shareholder wealth. Journal of Financial Economics 86, 306-336.

Gilson, S.C., 1990. Bankruptcy, boards, banks, and blockholders: evidence on changes in corporate ownership and control when firms default. Journal of Financial Economics 27, 355-388.

Goyal, V.K., Park, C.W., 2002. Board leadership structure and CEO turnover. Journal of Corporate Finance 8, 49-66.

Hermalin, B.E., Weisbach, M.S., 1988. The determinants of board composition. Rand Journal of Economics 19, 589-606.

Jensen, M.C., 1993. The modern industrial revolution, exit, and the failure of internal control systems. Working Paper.

Jones, J.J., 1991. Earnings management during import relief investigations. Journal of Accounting Research 29, 193-228.

Mace, M., 1971. Directors: Myth and Reality. Harvard Business School Press, Boston, Massachusetts.

Noe, T.H., 1997. Insider trading and the problem of corporate agency. Journal of Law, Economics, and Organization 13, 287-318.

Peck, S.W., 1996. The influence of professional investors on the failure of management buyout attempts. Journal of Financial Economics 40, 267-294.

Rosenstein, S., Wyatt, J.G., 1990. Outside directors, board independence, and shareholder wealth. Journal of Financial Economics 26, 175-192.

Journal of Corporate Finance, Vol. 16, No. 1 (February 2010): pg. 38-52. DOI. This article is (C) Elsevier and permission has been granted for this version to appear in e-Publications@Marquette. Elsevier does not grant permission for this article to be further copied/distributed or hosted elsewhere without the express permission from Elsevier 
NOT THE PUBLISHED VERSION; this is the author's final, peer-reviewed manuscript. The published version may be accessed by following the link in the citation at the bottom of the page.

Seyhun, N.H., 1992. The effectiveness of insider-trading sanctions. Journal of Law and Economics 35, 149-182.

Weisbach, M.S., 1988. Outside directors and CEO turnover. Journal of Financial Economics 20, 431-460.

Yermak, D., 2004. Remunerations, retention, and reputation incentives for outside directors. Journal of Finance 59, 2281-2309.

Xie, B., Davidson, W.N., DaDalt, P.J., 2003. Earnings management and corporate governance: the role of the board and the audit committee. Journal of Corporate Finance 9, 295-316.

\section{Appendix}

Table 1. Samples of outside director resignations from 1990 to 2003.

\begin{tabular}{|c|c|c|c|c|c|c|c|c|c|}
\hline \multicolumn{5}{|c|}{$\begin{array}{l}\text { Panel A: Sample of } 52 \text { announcements of } \\
\text { outside director resignations }\end{array}$} & \multicolumn{5}{|c|}{$\begin{array}{c}\text { Panel B: Random sample of } 52 \text { firms with } \\
\text { outside directors leaving with no public } \\
\text { announcement }\end{array}$} \\
\hline Year & $\begin{array}{c}\text { All } \\
\text { directo } \\
r \\
\text { resigna } \\
\text { tions } \\
\text { genera } \\
\text { ted by } \\
\text { key } \\
\text { word } \\
\text { search } \\
\text { of } \\
\text { Lexis- } \\
\text { Nexis } \\
\end{array}$ & $\begin{array}{c}\text { Outside } \\
\text { director } \\
\text { resignati } \\
\text { ons } \\
\text { verified } \\
\text { with } \\
\text { proxy } \\
\text { stateme } \\
\text { nt }\end{array}$ & $\begin{array}{c}\text { Number } \\
\text { of firms } \\
\text { in final } \\
\text { sample } \\
\text { meeting } \\
\text { data } \\
\text { requirem } \\
\text { ents }\end{array}$ & $\begin{array}{c}\text { Averag } \\
\text { e } \\
\text { number } \\
\text { of } \\
\text { outside } \\
\text { director } \\
\text { s } \\
\text { resigni } \\
\text { ng per } \\
\text { firm }\end{array}$ & $\begin{array}{c}\text { Firms } \\
\text { wher } \\
\text { e } \\
\text { outsi } \\
\text { de } \\
\text { direc } \\
\text { tor } \\
\text { left }\end{array}$ & $\begin{array}{c}\text { Number } \\
\text { of firms } \\
\text { meeting } \\
\text { data } \\
\text { requirem } \\
\text { ents }\end{array}$ & $\begin{array}{l}\text { Percenta } \\
\text { ge of } \\
\text { turnovers } \\
\text { meeting } \\
\text { data } \\
\text { requirem } \\
\text { ents that } \\
\text { are } \\
\text { publicly } \\
\text { announce } \\
\text { d }\end{array}$ & $\begin{array}{c}\text { Rand } \\
\text { Om } \\
\operatorname{samp} \\
\text { le }\end{array}$ & \begin{tabular}{|c} 
Averag \\
e \\
number \\
of \\
outside \\
directo \\
rs \\
leaving
\end{tabular} \\
\hline 1990 & 58 & 18 & 0 & {[} & $=$ & $=$ & - & - & {[} \\
\hline 1991 & 86 & 41 & 6 & 1.5 & I- & - & - & - & I- \\
\hline 1992 & 45 & 8 & 0 & $\varepsilon$ & I- & $=$ & - & $=$ & $=$ \\
\hline 1993 & 75 & 25 & 4 & 1.5 & + & - & $=$ & - & $=$ \\
\hline 1994 & 41 & 15 & 4 & 2.0 & I & $=$ & - & - & $E$ \\
\hline 1995 & 61 & 31 & 5 & 1.8 & I- & $=$ & - & $=$ & $=$ \\
\hline 1996 & 41 & 13 & 5 & 1.8 & 154 & 95 & 5.00 & 10 & 1.23 \\
\hline 1997 & 62 & 30 & 3 & 1.7 & 151 & 78 & 3.70 & 9 & 1.21 \\
\hline 1998 & 68 & 22 & 8 & 1.8 & 159 & 98 & 7.55 & 12 & 1.09 \\
\hline 1999 & 35 & 13 & 3 & 1.0 & 173 & 96 & 3.03 & 8 & 1.21 \\
\hline 2000 & 35 & 6 & 0 & $\varepsilon$ & 177 & 105 & 0.00 & 7 & 1.13 \\
\hline 2001 & 22 & 12 & 3 & 1.0 & 150 & 83 & 3.49 & 6 & 1.16 \\
\hline 2002 & 66 & 35 & 3 & 1.0 & 197 & $=$ & & - & I \\
\hline 2003 & 40 & 21 & 8 & 1.1 & 165 & - & & - & $=$ \\
\hline
\end{tabular}

Journal of Corporate Finance, Vol. 16, No. 1 (February 2010): pg. 38-52. DOI. This article is (C) Elsevier and permission has been granted for this version to appear in e-Publications@Marquette. Elsevier does not grant permission for this article to be further copied/distributed or hosted elsewhere without the express permission from Elsevier. 
NOT THE PUBLISHED VERSION; this is the author's final, peer-reviewed manuscript. The published version may be accessed by following the link in the citation at the bottom of the page.

\begin{tabular}{|c|c|c|c|c|c|c|c|c|c|}
\hline \multicolumn{5}{|c|}{$\begin{array}{l}\text { Panel A: Sample of } 52 \text { announcements of } \\
\text { outside director resignations }\end{array}$} & \multicolumn{5}{|c|}{$\begin{array}{c}\text { Panel B: Random sample of } 52 \text { firms with } \\
\text { outside directors leaving with no public } \\
\text { announcement }\end{array}$} \\
\hline Year & \begin{tabular}{|c|} 
All \\
directo \\
$r$ \\
resigna \\
tions \\
genera \\
ted by \\
key \\
word \\
search \\
of \\
Lexis- \\
Nexis
\end{tabular} & $\begin{array}{c}\text { Outside } \\
\text { director } \\
\text { resignati } \\
\text { ons } \\
\text { verified } \\
\text { with } \\
\text { proxy } \\
\text { stateme } \\
\text { nt }\end{array}$ & $\begin{array}{c}\text { Number } \\
\text { of firms } \\
\text { in final } \\
\text { sample } \\
\text { meeting } \\
\text { data } \\
\text { requirem } \\
\text { ents }\end{array}$ & $\begin{array}{c}\text { Averag } \\
\text { e } \\
\text { number } \\
\text { of } \\
\text { outside } \\
\text { director } \\
\text { s } \\
\text { resigni } \\
\text { ng per } \\
\text { firm }\end{array}$ & $\begin{array}{c}\text { Firms } \\
\text { wher } \\
\text { e } \\
\text { outsi } \\
\text { de } \\
\text { direc } \\
\text { tor } \\
\text { left }\end{array}$ & $\begin{array}{l}\text { Number } \\
\text { of firms } \\
\text { meeting } \\
\text { data } \\
\text { requirem } \\
\text { ents }\end{array}$ & \begin{tabular}{|c|} 
Percenta \\
ge of \\
turnovers \\
meeting \\
data \\
requirem \\
ents that \\
are \\
publicly \\
announce \\
d
\end{tabular} & $\begin{array}{c}\text { Rand } \\
\text { om } \\
\text { samp } \\
\text { le }\end{array}$ & $\begin{array}{c}\text { Averag } \\
\text { e } \\
\text { number } \\
\text { of } \\
\text { outside } \\
\text { directo } \\
\text { rs } \\
\text { leaving }\end{array}$ \\
\hline L & כנ & 290 & 52 & 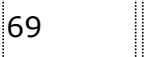 & {$\left[\begin{array}{l}1020 \\
0\end{array}\right.$} & 555 & & 52 & 72 \\
\hline
\end{tabular}

Notes: Outside directors are not employees, former employees or related to any employees of the firm, nor have any obvious affiliation with the firm or management, as disclosed in the firm's proxy statement or an independent director as defined by the IRRC database.

Table 2. Stated reasons for resignation on announcement for a sample of 52 announcements of outside director resignations from 1990-2003.

\begin{tabular}{|c|c|c|}
\hline & $\begin{array}{c}\text { Number of } \\
\text { announcements }\end{array}$ & $\begin{array}{l}\text { Percentage of } \\
\text { sample }\end{array}$ \\
\hline \multicolumn{3}{|l|}{ "Conflict" related reasons } \\
\hline Uncooperative management & 12 & $23 \%$ \\
\hline $\begin{array}{l}\text { Regulatory investigation or } \\
\text { shareholder lawsuit }\end{array}$ & 3 & $6 \%$ \\
\hline Director's ownership stake reduced & 2 & $4 \%$ \\
\hline Company poor performance & 2 & $4 \%$ \\
\hline Unknown & 7 & $13 \%$ \\
\hline Sub-total & 26 & $50 \%$ \\
\hline \multicolumn{3}{|l|}{ "Busy" related reasons } \\
\hline Other professional commitments & 17 & $33 \%$ \\
\hline Time constraint & 4 & $8 \%$ \\
\hline Family business & 3 & $6 \%$ \\
\hline Miscellaneous and health problems & 2 & $4 \%$ \\
\hline Sub-total & 26 & $50 \%$ \\
\hline Total & 52 & $100 \%$ \\
\hline
\end{tabular}

Notes: Outside directors are not employees, former employees or related to any employees of the firm, nor have any obvious affiliation with the firm or management,

Journal of Corporate Finance, Vol. 16, No. 1 (February 2010): pg. 38-52. DOI. This article is (C) Elsevier and permission has been granted for this version to appear in e-Publications@Marquette. Elsevier does not grant permission for this article to be further copied/distributed or hosted elsewhere without the express permission from Elsevier 
NOT THE PUBLISHED VERSION; this is the author's final, peer-reviewed manuscript. The published version may be accessed by following the link in the citation at the bottom of the page.

as disclosed in the firm's proxy statement or an independent director as defined by the IRRC database.

Table 3. Stock price reaction to announcement for a sample of 52 announcements of outside director resignations from 1990-2003.

\begin{tabular}{|c|c|c|c|c|}
\hline \multicolumn{3}{|c|}{ Event day } & \multicolumn{2}{|c|}{ Window $(-2,+1)$} \\
\hline $\begin{array}{l}\text { Resignation } \\
\text { reason }\end{array}$ & $\begin{array}{l}\text { Abnormal } \\
\text { return ( } \\
\text { statistic) }\end{array}$ & $\begin{array}{c}\text { Mean } \\
\text { standardized } \\
\text { prediction error } \\
\text { (number of } \\
\text { observations) }\end{array}$ & $\begin{array}{l}\text { Abnormal } \\
\text { return ( } Z \\
\text { statistic) }\end{array}$ & $\begin{array}{c}\text { Mean } \\
\text { standardized } \\
\text { prediction error } \\
\text { (number of } \\
\text { observations) }\end{array}$ \\
\hline All reasons & $\begin{array}{l}-0.57 \% \\
(-1.44)\end{array}$ & $-0.202(52)^{*}$ & $\begin{array}{l}-1.19 \% \\
(-0.918)\end{array}$ & -0.12952 \\
\hline $\begin{array}{l}\text { "Conflict" related } \\
\text { reasons }\end{array}$ & $\begin{array}{l}-1.17 \% \\
(-2.59)\end{array}$ & $-0.517(26)^{* *}$ & $\begin{array}{l}-3.10 \% \\
(-2.11)\end{array}$ & $-0.422(26)^{* *}$ \\
\hline $\begin{array}{l}\text { "Busy" related } \\
\text { reasons }\end{array}$ & $\begin{array}{l}0.03 \% \\
(0.57)\end{array}$ & $0.113(26)$ & $\begin{array}{l}0.72 \% \\
(0.83)\end{array}$ & $0.165(26)$ \\
\hline \multirow{2}{*}{$\begin{array}{l}\text { ANOVA test of } \\
\text { difference across } \\
\text { type of } \\
\text { resignation } \\
\text { reason }\end{array}$} & $F$-value & 2.15 & $F$-value & 2.49 \\
\hline & $p$-value & 0.0861 & $p$-value & 0.1211 \\
\hline
\end{tabular}

Notes: $*$ and $* *$ reflect statistical significance at the $10 \%$ level and $5 \%$ level respectively.

Abnormal returns are measured as the return minus a market model return. The market model is estimated as $E\left(r_{i t}\right)=a_{i t}+\beta_{i t}\left(R_{m t}\right)$. The CRSP (NASDAQ) valueweighted index is used as the market index for CRSP (NASDAQ) listed firms. The regression is estimated using 200 daily returns 120 days prior to the announcement. Statistical significance is based on $Z$ statistics calculated according to the standardized prediction errors method given in the appendix in Dodd and Warner (1983).

Outside directors are not employees, former employees or related to any employees of the firm, nor have any obvious affiliation with the firm or management, as disclosed in the firm's proxy statement or an independent director as defined by the IRRC database.

Journal of Corporate Finance, Vol. 16, No. 1 (February 2010): pg. 38-52. DOI. This article is @ Elsevier and permission has been granted for this version to appear in e-Publications@Marquette. Elsevier does not grant permission for this article to be further copied/distributed or hosted elsewhere without the express permission from Elsevier. 
NOT THE PUBLISHED VERSION; this is the author's final, peer-reviewed manuscript. The published version may be accessed by following the link in the citation at the bottom of the page.

Table 4. Characteristics of resigning directors for a sample of 104 firms with outside director resignations from 1990-2003 (percentages are of total number of directors for each column).

\begin{tabular}{|c|c|c|c|c|c|c|}
\hline & $\begin{array}{r}\text { Resigna } \\
\text { "conflic } \\
\text { rea }\end{array}$ & $\begin{array}{l}\text { tions for } \\
\text { sons } \\
\text { selated }\end{array}$ & $\begin{array}{r}\text { Resigna } \\
\text { "busy" } \\
\text { rea }\end{array}$ & $\begin{array}{l}\text { tions for } \\
\text { related } \\
\text { sons }\end{array}$ & $\begin{array}{c}\text { Directors } \\
\text { nonpubli }\end{array}$ & $\begin{array}{l}\text { eaving for } \\
\text { reasons }\end{array}$ \\
\hline & $\begin{array}{l}\text { Outside } \\
\text { directors } \\
\text { resigning }\end{array}$ & $\begin{array}{l}\text { Non- } \\
\text { resigning } \\
\text { outside } \\
\text { directors }\end{array}$ & $\begin{array}{l}\text { Outside } \\
\text { directors } \\
\text { resigning }\end{array}$ & $\begin{array}{l}\text { Non- } \\
\text { resigning } \\
\text { outside } \\
\text { directors }\end{array}$ & $\begin{array}{l}\text { Outside } \\
\text { directors } \\
\text { leaving }\end{array}$ & $\begin{array}{l}\text { Outside } \\
\text { directors } \\
\text { staying }\end{array}$ \\
\hline $\begin{array}{l}\text { Professional } \\
\text { director }\end{array}$ & $9.3 \% * * * a$ & 8.70 & 7.7 & 15.28 & 37.5 & $18.8 * * * b$ \\
\hline $\begin{array}{l}\text { Financial } \\
\text { professional }\end{array}$ & 30.2 & 21.7 & 19.2 & 25.00 & 19.4 & 17.6 \\
\hline $\begin{array}{l}\text { Other } \\
\text { professional }\end{array}$ & 48.8 & 56.0 & 50.0 & 46.53 & 33.3 & $(46.9)$ \\
\hline Other & 11.6 & 13.59 & 23.1 & 13.19 & 9.7 & 16.7 \\
\hline Total & 43 & 184 & 26 & 144 & 72 & 335 \\
\hline $\begin{array}{l}\text { Member of audit } \\
\text { committee }\end{array}$ & $60.5 \% * * * a$ & $42.93 * * b$ & 53.9 & 54.86 & 31.9 & $45.1 * * b$ \\
\hline $\begin{array}{l}\text { Member of } \\
\text { compensation } \\
\text { committee }\end{array}$ & $53.5 * * * a$ & 45.65 & 34.6 & 54.17 & 18.05 & 47.2 \\
\hline $\begin{array}{l}\text { Member of } \\
\text { nominating } \\
\text { committee }\end{array}$ & 12.82 & 87.2 & 14.6 & 24.3 & 20.8 & $35.2 * * b$ \\
\hline $\begin{array}{l}\text { Average age } \\
\text { (median) }\end{array}$ & $\begin{array}{l}55.0 * * * c \\
(55) * * * c\end{array}$ & $55.8(56)$ & $\begin{array}{l}58.26 \\
(58)^{* * * d}\end{array}$ & $58.9(60)$ & $\begin{array}{l}64.4 * * * \mathrm{e} \\
* * * \mathrm{f} \\
(67) * * * \mathrm{e} \\
* * * \mathrm{f}\end{array}$ & $\begin{array}{l}58.6 * * * g \\
(59)\end{array}$ \\
\hline $\begin{array}{l}\text { Average } \\
\text { percentage stock } \\
\text { ownership by } \\
\text { director (median) }\end{array}$ & $\begin{array}{l}1.33 \% \\
(0.05)\end{array}$ & $\begin{array}{l}0.02 * * * g \\
(0.00)\end{array}$ & $0.06(0.02)$ & $0.07(0.00)$ & $\begin{array}{l}0.08 \\
(0.00) * f\end{array}$ & $\begin{array}{l}0.06 \\
(0.00) * * g\end{array}$ \\
\hline $\begin{array}{l}\text { Average director } \\
\text { tenure (years) } \\
\text { (median) }\end{array}$ & $\begin{array}{l}6.9 * * *_{C} \\
(3.5) * * * c\end{array}$ & $6.8(5.0)$ & $5.8(4.0)$ & $7.9(6.0)$ & $\begin{array}{l}14.6 * * * \mathrm{e} \\
* * * \mathrm{f}(11.0)\end{array}$ & $\begin{array}{l}7.9 * * * g \\
(6.0) * * * g\end{array}$ \\
\hline $\begin{array}{l}\text { Average number } \\
\text { of years served } \\
\text { with CEO } \\
\text { (median) }\end{array}$ & $4.1 * c(3.0)$ & $4.4(4.0)$ & $4.7(3.0)$ & $5.1(3.0)$ & $5.9(4.0)$ & $\begin{array}{l}4.4^{* *} g \\
(3.0)\end{array}$ \\
\hline $\begin{array}{l}\text { Average CEO } \\
\text { tenure/director } \\
\text { tenure (median) }\end{array}$ & $\begin{array}{l}2.5 \\
(1.8) * * * \mathrm{C}\end{array}$ & $2.1(1.3)$ & $\begin{array}{l}4.3 * * * d \\
(2.0) * * * d\end{array}$ & $\begin{array}{l}2.6 \\
(1.1) * * f\end{array}$ & $\begin{array}{l}1.4 * * \mathrm{f} \\
(0.5) * * * \mathrm{e} \\
* * * \mathrm{f}\end{array}$ & 1.9 \\
\hline
\end{tabular}

Notes: $*, * *$, and $* * *$ reflect statistical significance at the $10 \%, 5 \%$ and $1 \%$ level respectively. Differences in frequencies tested using a chi-square test; differences in means tested using a Student's $t$-test; differences in medians tested using Wilcoxon signed rank test. been granted for this version to appear in e-Publications@Marquette. Elsevier does not grant permission for this article to be further copied/distributed or hosted elsewhere without the express permission from Elsevier. 
NOT THE PUBLISHED VERSION; this is the author's final, peer-reviewed manuscript. The published version may be accessed by following the link in the citation at the bottom of the page.

a Denotes the statistical significance of the association between the type of director resigning or committee membership and the reason given.

b Denotes the statistical significance of the association between the resigning and nonresigning director types and committee membership within each of the three subsamples for the reason given for resignation.

c Denotes the statistical significance of difference between firms with "conflict" related resignations versus all others.

d Denotes the statistical significance of difference between firms with "conflict" related resignations versus firms with "busy" related resignations.

e Denotes the statistical significance of difference between firms with "conflict" related resignations versus firms with non-public resignations.

f Denotes the statistical significance of difference between firms with "busy" related resignations versus firms with non-public resignations.

$\mathrm{g}$ Denotes the statistical significance of the difference between resigning directors and directors who stay within the same firm.

Data is collected using the proxy statement prior to the resignation announcement or the year prior to the resignation year using the IRRC database.

Professional directors are executives that have retired from their primary profession.

Financial professionals include accountants, commercial bankers, corporate finance executives, investment professionals, individual investors, commercial bankers, and accountants.

Other professionals include corporate executives, lawyers, and consultants.

Others include academics, past or current government officials or members of public policy commissions, philanthropists, or members of other professions.

Stock ownership is defined as all beneficially owned stock, including options exercisable within six months and stock held by family members that the board member disclaims any beneficial interest in.

Outside directors are not employees, former employees or related to any employees of the firm, nor have any obvious affiliation with the firm or management, as disclosed in the firm's proxy statement or an independent director as defined by the IRRC database.

Journal of Corporate Finance, Vol. 16, No. 1 (February 2010): pg. 38-52. DOI. This article is (c) Elsevier and permission has been granted for this version to appear in e-Publications@Marquette. Elsevier does not grant permission for this article to be further copied/distributed or hosted elsewhere without the express permission from Elsevier. 
NOT THE PUBLISHED VERSION; this is the author's final, peer-reviewed manuscript. The published version may be accessed by following the link in the citation at the bottom of the page.

Table 5. Characteristics of boards for a sample of 104 firms with outside director resignations from 1990-2003 (percentages are of total number of directors for each column).

\begin{tabular}{|c|c|c|c|}
\hline & $\begin{array}{c}\text { Firms with outside } \\
\text { directors resigning } \\
\text { for "conflict" } \\
\text { related reasons }\end{array}$ & $\begin{array}{c}\text { Firms with outside } \\
\text { directors resigning } \\
\text { for "busy" related } \\
\text { reasons }\end{array}$ & $\begin{array}{c}\text { Firms with outside } \\
\text { directors leaving with } \\
\text { no public } \\
\text { announcement }\end{array}$ \\
\hline \multicolumn{4}{|l|}{ Total board } \\
\hline $\begin{array}{l}\text { Professional } \\
\text { director }\end{array}$ & $5.85 \%$ & 9.96 & $17.05^{* * * a}$ \\
\hline $\begin{array}{l}\text { Financial } \\
\text { professional }\end{array}$ & 15.50 & 17.01 & 13.83 \\
\hline $\begin{array}{l}\text { Other } \\
\text { professional }\end{array}$ & 36.55 & 32.78 & 34.28 \\
\hline Other & 8.77 & 9.96 & 11.93 \\
\hline Insider & 33.33 & 30.29 & 22.92 \\
\hline Total & 342 & 241 & 528 \\
\hline \multicolumn{4}{|c|}{ Audit committee } \\
\hline $\begin{array}{l}\text { Professional } \\
\text { director }\end{array}$ & $5.13 \%$ & 17.20 & $25.84 * * * a$ \\
\hline $\begin{array}{l}\text { Financial } \\
\text { professional }\end{array}$ & 29.91 & 30.11 & 15.17 \\
\hline $\begin{array}{l}\text { Other } \\
\text { professional }\end{array}$ & 45.30 & 35.48 & 44.94 \\
\hline Other & 9.40 & 17.20 & 11.80 \\
\hline Insider & 10.26 & 0.00 & 2.25 \\
\hline Total & 117 & 93 & 178 \\
\hline \multicolumn{4}{|c|}{ Compensation committee } \\
\hline $\begin{array}{l}\text { Professional } \\
\text { director }\end{array}$ & $6.56 \%$ & 20.22 & $23.12 * * * a$ \\
\hline $\begin{array}{l}\text { Financial } \\
\text { professional }\end{array}$ & 21.31 & 31.46 & 14.45 \\
\hline $\begin{array}{l}\text { Other } \\
\text { professional }\end{array}$ & 51.64 & 37.08 & 49.71 \\
\hline Other & 9.02 & 8.99 & 11.56 \\
\hline Insider & 11.48 & 2.25 & 1.16 \\
\hline Total & 122 & 89 & 173 \\
\hline \multicolumn{4}{|c|}{ Nominating committee } \\
\hline $\begin{array}{l}\text { Professional } \\
\text { director }\end{array}$ & $8.70 \%$ & 13.21 & 23.40 \\
\hline
\end{tabular}

Journal of Corporate Finance, Vol. 16, No. 1 (February 2010): pg. 38-52. DOI. This article is (c) Elsevier and permission has been granted for this version to appear in e-Publications@Marquette. Elsevier does not grant permission for this article to be further copied/distributed or hosted elsewhere without the express permission from Elsevier. 
NOT THE PUBLISHED VERSION; this is the author's final, peer-reviewed manuscript. The published version may be accessed by following the link in the citation at the bottom of the page.

\begin{tabular}{|c|c|c|c|}
\hline & $\begin{array}{c}\text { Firms with outside } \\
\text { directors resigning } \\
\text { for "conflict" } \\
\text { related reasons }\end{array}$ & $\begin{array}{c}\text { Firms with outside } \\
\text { directors resigning } \\
\text { for "busy" related } \\
\text { reasons }\end{array}$ & $\begin{array}{c}\text { Firms with outside } \\
\text { directors leaving with } \\
\text { no public } \\
\text { announcement }\end{array}$ \\
\hline $\begin{array}{l}\text { Financial } \\
\text { professional }\end{array}$ & 6.52 & 15.09 & 14.18 \\
\hline $\begin{array}{l}\text { Other } \\
\text { professional }\end{array}$ & 56.52 & 33.93 & 43.26 \\
\hline Other & 13.04 & 15.09 & 13.48 \\
\hline Insider & 15.22 & 22.64 & 5.67 \\
\hline Total & 46 & 53 & 141 \\
\hline
\end{tabular}

Notes: $*, * *$, and $* * *$ reflect statistical significance at the $10 \%, 5 \%$ and $1 \%$ level respectively. Differences in frequencies tested using a chi-square test.

a Denotes the statistical significance between the association of director type and committee membership and the reason given for the resignation.

Data is collected using the proxy statement prior to the resignation announcement of the year prior to the resignation year in the IRRC database.

Professional directors are executives that have retired from their primary profession.

Financial professionals include (both retired and active) accountants, commercial bankers, corporate finance executives, investment professionals, individual investors, commercial bankers, and accountants.

Other professionals include corporate executives, lawyers, and consultants.

Others include academics, past or current government officials or members of public policy commissions, philanthropists, or members of other professions.

Outside directors are not employees, former employees or related to any employees of the firm, nor have any obvious affiliation with the firm or management, as disclosed in the firm's proxy statement or independent directors as defined by the IRRC database.

Journal of Corporate Finance, Vol. 16, No. 1 (February 2010): pg. 38-52. DOI. This article is (C) Elsevier and permission has been granted for this version to appear in e-Publications@Marquette. Elsevier does not grant permission for this article to be further copied/distributed or hosted elsewhere without the express permission from Elsevier. 
NOT THE PUBLISHED VERSION; this is the author's final, peer-reviewed manuscript. The published version may be accessed by following the link in the citation at the bottom of the page.

Table 6. Firm characteristics for a sample of 104 firms with outside director resignations from 1990-2003.

\begin{tabular}{|c|c|c|c|}
\hline & $\begin{array}{l}\text { Firms with } \\
\text { resignation } \\
\text { announcements } \\
\text { for "conflict" } \\
\text { related reasons }\end{array}$ & $\begin{array}{c}\text { Firms with } \\
\text { resignation } \\
\text { announcements } \\
\text { for "busy" related } \\
\text { reasons }\end{array}$ & $\begin{array}{c}\text { Firms with } \\
\text { outside directors } \\
\text { leaving with no } \\
\text { public } \\
\text { announcement }\end{array}$ \\
\hline \multicolumn{4}{|c|}{ Panel A: Board characteristics } \\
\hline $\begin{array}{l}\text { Average percentage of } \\
\text { outside directors on the } \\
\text { board (median) }\end{array}$ & $\begin{array}{l}66.60 \% * * * a \\
(70.00) * * * a\end{array}$ & $72.14(71.36)$ & $\begin{array}{l}76.73 * * * \mathrm{c} \\
(78.89) * * * c\end{array}$ \\
\hline Board size & $\begin{array}{l}8.12 * * * a \\
(8.00) * * * a\end{array}$ & $9.46(8.00) * * * d$ & {$\left[\begin{array}{l}10.15 * * * c \\
(10.00) * * * c\end{array}\right.$} \\
\hline $\begin{array}{l}\text { Percentage of firms } \\
\text { where CEO is chairman } \\
\text { of the board }\end{array}$ & $61.54 \% \square a$ & $38.46 \square \mathrm{b}$ & 40.38 \\
\hline $\begin{array}{l}\text { Average percentage } \\
\text { stock ownership of all } \\
\text { outside directors } \\
\text { (median) }\end{array}$ & $0.037 \%(1.21)$ & $5.89(0.90)$ & $4.73(0.58)$ \\
\hline $\begin{array}{l}\text { Annual retainer fee as } \\
\text { a percentage of sales } \\
\text { (median) }\end{array}$ & $\begin{array}{l}0.029623 \% \\
(0.005823)\end{array}$ & $\begin{array}{l}0.004755 \\
(0.001657) * b\end{array}$ & $\begin{array}{l}0.016403 \\
(0.011228)\end{array}$ \\
\hline $\begin{array}{l}\text { Average percentage of } \\
\text { directors resigning } \\
\text { (median) }\end{array}$ & {$\left[\begin{array}{l}24.48 \% * * * a \\
(20.00)^{* * * a} a\end{array}\right.$} & $\begin{array}{l}14.56 * * * b \\
(12.50) * * * b, * d\end{array}$ & $\begin{array}{l}17.55^{* *} \mathrm{c} \\
(14.29)^{* *} \mathrm{c}\end{array}$ \\
\hline $\begin{array}{l}\text { Average percentage of } \\
\text { outsider directors } \\
\text { resigning (median) }\end{array}$ & $\begin{array}{l}39.47 \% * * * a \\
(30.95) * * a\end{array}$ & $\begin{array}{l}20.35 \% * * * \mathrm{~b} \\
(16.67) * * * \mathrm{~b}\end{array}$ & $\begin{array}{l}20.39 * * *_{C} \\
(18.18)^{* * *} \mathrm{C} \\
\end{array}$ \\
\hline $\begin{array}{l}\text { Percentage of firms } \\
\text { where an inside } \\
\text { director also resigns }\end{array}$ & $24.48 \%$ & $14.56 * * * b, * * * d$ & 30.77 \\
\hline \multicolumn{4}{|c|}{ Panel B: CEO characteristics } \\
\hline Average age (median) & $51.12 * a(50) * a$ & $53.88(53)$ & $55.77 * *_{c}(56) * *_{c}$ \\
\hline $\begin{array}{l}\text { Average total cash } \\
\text { compensation as a } \\
\text { percentage of sales } \\
\text { (median) }\end{array}$ & $0.77 \%(0.25)$ & $0.45(0.16)$ & $0.96^{* *} c(0.49)$ \\
\hline $\begin{array}{l}\text { Average percentage } \\
\text { stock ownership } \\
\text { (median) }\end{array}$ & $6.68 \% * a(2.13) * a$ & $5.19(0.76)$ & {$\left[\begin{array}{l}2.27 * * c \\
(0.59) * * * c\end{array}\right.$} \\
\hline $\begin{array}{l}\text { Average stock options } \\
\text { granted as percentage } \\
\text { of shares outstanding } \\
\text { (median) }\end{array}$ & $0.03 \%(0.00)$ & $0.00(0.00)$ & $0.00(0.00) * * * c$ \\
\hline $\begin{array}{l}\text { Average total } \\
\text { compensation as a }\end{array}$ & $0.80 \% * * a(0.36)$ & $0.47(0.16)$ & $\begin{array}{l}3.91 * \mathrm{c}, * * * \mathrm{~d} \\
(1.15) * * * \mathrm{c}, * * * d\end{array}$ \\
\hline
\end{tabular}

Journal of Corporate Finance, Vol. 16, No. 1 (February 2010): pg. 38-52. DOI. This article is (c) Elsevier and permission has been granted for this version to appear in e-Publications@Marquette. Elsevier does not grant permission for this article to be further copied/distributed or hosted elsewhere without the express permission from Elsevier. 
NOT THE PUBLISHED VERSION; this is the author's final, peer-reviewed manuscript. The published version may be accessed by following the link in the citation at the bottom of the page.

\begin{tabular}{|c|c|c|c|}
\hline & $\begin{array}{c}\text { Firms with } \\
\text { resignation } \\
\text { announcements } \\
\text { for "conflict" } \\
\text { related reasons } \\
\end{array}$ & $\begin{array}{c}\text { Firms with } \\
\text { resignation } \\
\text { announcements } \\
\text { for "busy" related } \\
\text { reasons }\end{array}$ & $\begin{array}{c}\text { Firms with } \\
\text { outside directors } \\
\text { leaving with no } \\
\text { public } \\
\text { announcement }\end{array}$ \\
\hline \multicolumn{4}{|l|}{$\begin{array}{l}\text { percentage of sales } \\
\text { (median) }\end{array}$} \\
\hline $\begin{array}{l}\text { Average total } \\
\text { compensation as a } \\
\text { percentage of EBITDA } \\
\text { (median) }\end{array}$ & $20.59 \%(3.07)$ & $4.12(2.65)$ & $\begin{array}{l}20.88 * * * d \\
(9.80) * * * c, * * * d\end{array}$ \\
\hline $\begin{array}{l}\text { Average CEO tenure } \\
\text { (years) (median) }\end{array}$ & $7.21(6.5)$ & $10.58 * b(8)$ & $8.27(6)$ \\
\hline \multicolumn{4}{|c|}{ Panel C: Outside ownership characteristics } \\
\hline $\begin{array}{l}\text { Average number of } \\
\text { outside blockholders } \\
\text { (median) }\end{array}$ & $2.31(2)$ & $1.88(2)$ & $1.67 * \mathrm{c}(2)$ \\
\hline $\begin{array}{l}\text { Average percentage of } \\
\text { shares outstanding } \\
\text { held by outside } \\
\text { blockholders (median) }\end{array}$ & $13.81 \%(9.96)$ & $6.87(7.38) * * * b$ & $\begin{array}{l}15.62 * * * d \\
(13.38)\end{array}$ \\
\hline \multicolumn{4}{|c|}{ Panel D: Firm performance } \\
\hline $\begin{array}{l}\text { Average total assets in } \\
\text { year prior to } \\
\text { resignation year } \\
(\$ \text { millions }) \text { (median) }\end{array}$ & $\$ 3848.57(80.08)$ & $\begin{array}{l}2590.18 \\
(441.37) * b\end{array}$ & $\begin{array}{l}582.02 * * d \\
(185.23)\end{array}$ \\
\hline $\begin{array}{l}\text { Average total sales in } \\
\text { year prior to } \\
\text { resignation year } \\
(\$ \text { millions }) \text { (median) }\end{array}$ & $\$ 2911.84(212.88)$ & $3754.95(425.36)$ & $\begin{array}{l}764.08 * * d \\
(142.04)\end{array}$ \\
\hline $\begin{array}{l}\text { Average beta in year } \\
\text { prior to resignation } \\
\text { year (median) }\end{array}$ & $0.60 * a(0.47)^{* * * a}$ & $0.90 * b(0.91) * b$ & $0.95 * c(0.77) * c$ \\
\hline $\begin{array}{l}\text { Average change in } \\
\text { sales from prior } \\
\text { year/total beginning } \\
\text { period assets two years } \\
\text { prior to resignation } \\
\text { year (median) }\end{array}$ & $0.18(0.09)$ & $0.25(0.21)$ & $\begin{array}{l}0.002 * * * d \\
(0.00) * * * c, * * * d\end{array}$ \\
\hline $\begin{array}{l}\text { Average change in } \\
\text { sales from prior } \\
\text { year/total beginning } \\
\text { period assets in year } \\
\text { prior to resignation } \\
\text { year (median) }\end{array}$ & $\begin{array}{l}0.08 * * * a \\
(0.00) * * * a\end{array}$ & $0.21(0.07) * b$ & $\begin{array}{l}1.78 * * * d, * * * c \\
(0.95) * * *{ }_{c}, * * * d\end{array}$ \\
\hline $\begin{array}{l}\text { Average change in } \\
\text { EBITDA from prior }\end{array}$ & $35.66 * a(0.00)$ & $\begin{array}{l}0.61 * b \\
(-0.00) * * * b\end{array}$ & $0.00(0.00)^{* * * d}$ \\
\hline
\end{tabular}

Journal of Corporate Finance, Vol. 16, No. 1 (February 2010): pg. 38-52. DOI. This article is (c) Elsevier and permission has been granted for this version to appear in e-Publications@Marquette. Elsevier does not grant permission for this article to be further copied/distributed or hosted elsewhere without the express permission from Elsevier. 
NOT THE PUBLISHED VERSION; this is the author's final, peer-reviewed manuscript. The published version may be accessed by following the link in the citation at the bottom of the page.

\begin{tabular}{|c|c|c|c|}
\hline & $\begin{array}{l}\text { Firms with } \\
\text { resignation } \\
\text { announcements } \\
\text { for "conflict" } \\
\text { related reasons }\end{array}$ & $\begin{array}{c}\text { Firms with } \\
\text { resignation } \\
\text { announcements } \\
\text { for "busy" related } \\
\text { reasons }\end{array}$ & $\begin{array}{c}\text { Firms with } \\
\text { outside directors } \\
\text { leaving with no } \\
\text { public } \\
\text { announcement }\end{array}$ \\
\hline \multicolumn{4}{|l|}{$\begin{array}{l}\text { year/total beginning } \\
\text { period assets two years } \\
\text { prior to resignation } \\
\text { year (median) }\end{array}$} \\
\hline $\begin{array}{l}\text { Average change in } \\
\text { EBITDA from prior } \\
\text { year/total beginning } \\
\text { period assets in year } \\
\text { prior to resignation } \\
\text { year (median) }\end{array}$ & {$\left[\begin{array}{l}-0.54 * * a \\
(-0.01)^{* * a}, * * * e\end{array}\right.$} & $0.39(0.00) * b$ & $\begin{array}{l}0.26 * * c \\
(0.22)^{* * *} \mathrm{c}, * d\end{array}$ \\
\hline $\begin{array}{l}\text { Average EBITDA/total } \\
\text { beginning period assets } \\
\text { in year prior to } \\
\text { resignation year } \\
\text { (median) }\end{array}$ & {$\left[\begin{array}{l}-1.26 * * * a \\
(0.010) * * * a\end{array}\right.$} & $-0.03(0.01)$ & {$\left[\begin{array}{l}1.87 * * * \mathrm{c}, * * * \mathrm{~d} \\
(1.76) * * * \mathrm{c}, * * * \mathrm{~d}\end{array}\right.$} \\
\hline $\begin{array}{l}\text { Average sales/total } \\
\text { beginning period assets } \\
\text { in year prior to } \\
\text { resignation year } \\
\text { (median) }\end{array}$ & $\begin{array}{l}1.58 * * * a \\
(1.21) * * * a\end{array}$ & $1.36(1.07)$ & $\begin{array}{l}14.76 * * * \mathrm{c}, * * * \mathrm{~d} \\
(12.05) * * * \mathrm{c}, * * * \mathrm{~d}\end{array}$ \\
\hline $\begin{array}{l}\text { Average annual } \\
\text { percentage sales } \\
\text { growth in the three } \\
\text { years prior to } \\
\text { resignation year } \\
\text { (median) }\end{array}$ & $15.26 \%(8.43)$ & $21.01(12.15)$ & $15.62(8.00)$ \\
\hline $\begin{array}{l}\text { Average operating } \\
\text { margins in year prior to } \\
\text { resignation year } \\
\text { (median) }\end{array}$ & $\begin{array}{l}-10.25 \% * * a \\
(0.01) * * * a\end{array}$ & $-0.44(0.00)$ & $0.18 * c(0.16) * * * c$ \\
\hline $\begin{array}{l}\text { Percentage of firms } \\
\text { reporting a loss }\end{array}$ & $53.85 \% * * * a$ & 38.46 & $7.69 * * * c$ \\
\hline $\begin{array}{l}\text { Average change in } \\
\text { (total } \\
\text { accruals/beginning } \\
\text { period sales) in year } \\
\text { prior to resignation } \\
\text { year (median) }\end{array}$ & $\begin{array}{l}0.32 * * * a \\
(0.02) * * * a\end{array}$ & $0.01 * b(-0.00) * b$ & $\begin{array}{l}-0.44 * * * \mathrm{c}, * * * d \\
(-0.42) * * * \mathrm{c}, \\
* * * \mathrm{~d}\end{array}$ \\
\hline $\begin{array}{l}\text { Average market } \\
\text { adjusted stock return } \\
\text { performance six } \\
\text { months prior to } \\
\text { resignation ( } p \text {-value for } \\
\text { test of difference from } \\
\text { zero) (median) }\end{array}$ & {$\left[\begin{array}{l}-17.90 \% * * * a \\
(0.0477) \\
(-10.246)\end{array}\right.$} & $\begin{array}{l}3.29 * * * b(0.5458) \\
(0.45)\end{array}$ & {$\left[\begin{array}{l}-9.12 * * * c \\
(0.0254)(-4.92)\end{array}\right.$} \\
\hline
\end{tabular}

Journal of Corporate Finance, Vol. 16, No. 1 (February 2010): pg. 38-52. DOI. This article is (c) Elsevier and permission has been granted for this version to appear in e-Publications@Marquette. Elsevier does not grant permission for this article to be further copied/distributed or hosted elsewhere without the express permission from Elsevier. 
NOT THE PUBLISHED VERSION; this is the author's final, peer-reviewed manuscript. The published version may be accessed by following the link in the citation at the bottom of the page.

\begin{tabular}{|l|l|l|l|}
\hline & $\begin{array}{c}\text { Firms with } \\
\text { resignation } \\
\text { announcements } \\
\text { for "conflict" } \\
\text { related reasons }\end{array}$ & $\begin{array}{c}\text { Firms with } \\
\text { resignation } \\
\text { announcements } \\
\text { for "busy" related } \\
\text { reasons }\end{array}$ & $\begin{array}{c}\text { Firms with } \\
\text { outside directors } \\
\text { leaving with no } \\
\text { public } \\
\text { announcement }\end{array}$ \\
\hline $\begin{array}{l}\text { Average market } \\
\text { adjusted stock return } \\
\text { performance twelve } \\
\text { months prior to } \\
\text { resignation }(p \text {-value for } \\
\text { test of difference from } \\
\text { zero) (median) }\end{array}$ & $\begin{array}{l}(-40.44 * * * a \\
(9.0001)(-5.26)\end{array}$ & $\begin{array}{l}(0.54) * * * b \\
(0.563)(0.35)\end{array}$ & {$\left[\begin{array}{l}0.2495) \\
(-10.23)\end{array}\right.$} \\
\hline
\end{tabular}

Notes: $*, * *$, and $* * *$ reflect statistical significance at the $10 \%, 5 \%$ and $1 \%$ level respectively. Differences in frequencies tested using a chi-square test; differences in means tested using a Student's $t$-test; differences in medians tested using Wilcoxon signed rank test.

a Denotes the statistical significance of difference between firms with "conflict" related resignations versus all others.

b Denotes the statistical significance of difference between firms with "conflict" related resignations versus firms with "busy" related resignations.

c Denotes the statistical significance of difference between firms with "conflict" related resignations versus firms with non-public resignations.

d Denotes the statistical significance of difference between firms with "busy" related resignations versus firms with non-public resignations.

e Denotes the statistical significance of differences in changes in performance between the two years prior and one year prior to the resignation year for each resignation type sub-sample.

Data is collected using the proxy statement prior to the resignation announcement or the year prior to the resignation year in the IRRC data base.

Stock ownership is defined as all beneficially owned stock, including options exercisable within six months and stock held by family members that the board member or executive disclaims any beneficial interest in.

The value of stock options is estimated using Black Scholes. Monthly return volatility is estimated using up to 60 months worth of return data in period prior to option grant (minimum number of observations used is 44 ). When time to maturity or average time to maturity is missing 10 years is used. When the average exercise price and/or grant date is missing, the stock price at the time of grant or at the time the proxy statement is prepared is used.

Outside blockholders are $5 \%$ of more beneficial owners of stock with no obvious affiliation with management as disclosed in the proxy statement and include insurance companies, banks, mutual funds, public and private mutual funds, and investment firms. been granted for this version to appear in e-Publications@Marquette. Elsevier does not grant permission for this article to be further copied/distributed or hosted elsewhere without the express permission from Elsevier. 
NOT THE PUBLISHED VERSION; this is the author's final, peer-reviewed manuscript. The published version may be accessed by following the link in the citation at the bottom of the page.

Outside directors are not employees, former employees or related to any employees of the firm, nor have any obvious affiliation with the firm or management, as disclosed in the firm's proxy statement or independent directors as defined in the IRRC data base.

All financial data is measured for first (second, third) full fiscal year end prior to year in which resignation is announced.

Data is collected from Compustat using Research Insight.

Total accruals are measured as $\mathrm{TA}_{\mathrm{t}}=\Delta \mathrm{CA}_{\mathrm{t}}-\Delta \mathrm{Cash}_{\mathrm{t}}-\Delta \mathrm{CL}_{\mathrm{t}}+\Delta \mathrm{STD}_{\mathrm{t}}-\mathrm{Dep}_{\mathrm{t}}$; where $\mathrm{TA}=$ total accruals; $\triangle \mathrm{CA}=$ change in current assets; $\triangle$ Cash $=$ change in cash and cash equivalents; $\triangle \mathrm{CL}=$ change in current liabilities; $\triangle \mathrm{STD}=$ change in debt included in current liabilities; Dep $=$ Depreciation and amortization expense.

Differences in changes in performance, EBITDA and Sales, between two years prior and one year prior to the resignation year are tested for each type of resignation announcements sub-sample. There are no statistically significant differences in year to year changes in performance measures for firms with resignations announcements for "busy" related reasons or resignations that are non-public or year to year changes in sales for firms with resignations announcements for "conflict" related reasons. The median change in EBITDA scaled by assets year to year is statistically significantly different at the $1 \%$ level for firms with resignation announcements for "conflict" related reasons.

Month 1 is the month following the resignation announcements for the announcement sample. For the comparison sample, Month 1 is January in the year following the resignation year. Monthly returns for each firm in the sample as well as the return on S\&P 500 are collected starting in the month following the resignation announcement. The market-adjusted performance for each firm for each time period is computed as the geometric mean of $1+$ the firm's performance minus the geometric mean of $1+$ market's performance for 6 or 12 months following the announcement month. To limit the influence of outliers on statistical tests market adjusted performance is Winsorized at the $5 \%$ level.

Journal of Corporate Finance, Vol. 16, No. 1 (February 2010): pg. 38-52. DOI. This article is (c) Elsevier and permission has been granted for this version to appear in e-Publications@Marquette. Elsevier does not grant permission for this article to be further copied/distributed or hosted elsewhere without the express permission from Elsevier. 
NOT THE PUBLISHED VERSION; this is the author's final, peer-reviewed manuscript. The published version may be accessed by following the link in the citation at the bottom of the page.

Table 7. Parameter estimates for logistic regression of reason is given with resignation for a sample of 104 firms with outside director resignations from 1990-2003 ( $p$-values in parentheses).

\begin{tabular}{|c|c|c|c|}
\hline & $\begin{array}{c}\text { Likelihood that a } \\
\text { "conflict" related } \\
\text { reason is given at } \\
\text { outsider's } \\
\text { resignation } \\
\text { announcement }\end{array}$ & $\begin{array}{c}\text { Likelihood that a } \\
\text { "busy" related } \\
\text { reason is given at } \\
\text { outsider's } \\
\text { resignation } \\
\text { announcement }\end{array}$ & $\begin{array}{l}\text { Likelihood that } \\
\text { an outside } \\
\text { director leaves } \\
\text { with no public } \\
\text { announcement }\end{array}$ \\
\hline \multicolumn{4}{|c|}{ Parameter } \\
\hline Intercept & - $1.1254(0.5799)$ & -2.3155 & $\begin{array}{l}-7.5606 \\
(<0.0001)\end{array}$ \\
\hline $\begin{array}{l}\text { Director is a } \\
\text { professional director }\end{array}$ & $0.3978(0.5718)$ & $0.0523(0.8806)$ & $1.4252(<0.0001)$ \\
\hline $\begin{array}{l}\text { Director is a finance } \\
\text { professional }\end{array}$ & $0.8608(0.0726)$ & 0.05 & $0.3767(0.3785)$ \\
\hline Age of director & {$[-0.0252(0.2358)$} & $0.0385(0.0028)$ & $0.0706(0.0001)$ \\
\hline $\begin{array}{l}\text { Percentage stock } \\
\text { ownership by director }\end{array}$ & {$[-9.3457(0.3797)$} & $3.0751(0.1852)$ & $-2.459(0.5758)$ \\
\hline $\begin{array}{l}\text { CEO tenure/director } \\
\text { tenure }\end{array}$ & $0.0221(0.7527)$ & $0.0996(0.0019)$ & $-0.0194(0.7501)$ \\
\hline $\begin{array}{l}\text { Director is on audit } \\
\text { committee }\end{array}$ & $0.8446(0.0720)$ & 0.160 & $-0.5748(0.0739)$ \\
\hline $\begin{array}{l}\text { Director is on } \\
\text { compensation } \\
\text { committee }\end{array}$ & $0.9246(0.0422)$ & 0.09 & $-1.3203(0.0003)$ \\
\hline $\begin{array}{l}\text { Director is on } \\
\text { nominating committee }\end{array}$ & $-0.2508(0.6808)$ & $-0.1179(0.6360)$ & $-0.2544(0.4769)$ \\
\hline Board size & $-0.067(0.5628)$ & $-0.1305(0.0050)$ & $-0.0803(0.3252)$ \\
\hline $\begin{array}{l}\text { Percentage of outside } \\
\text { directors on the board }\end{array}$ & [- $0.0128(0.5239)$ & $0.0469(<0.0001)$ & $\begin{array}{l}-0.00285 \\
(0.8271)\end{array}$ \\
\hline $\begin{array}{l}\text { CEO is chairman of } \\
\text { the board }\end{array}$ & $-0.0206(0.9675)$ & {$\left[\begin{array}{l}-1.2132 \\
(<0.0001)\end{array}\right.$} & $0.5479(0.0985)$ \\
\hline $\begin{array}{l}\text { CEO total } \\
\text { compensation as a } \\
\text { percentage of sales }\end{array}$ & - $0.2758(0.3625)$ & {$\left[\begin{array}{l}-1.9994 \\
(<0.0001)\end{array}\right.$} & $0.0284(0.0884)$ \\
\hline $\begin{array}{l}\text { Percentage of shares } \\
\text { outstanding held by } \\
\text { outside blockholders }\end{array}$ & $0.0082(0.7472)$ & {$\left[\begin{array}{l}-0.1431 \\
(<0.0001)\end{array}\right.$} & $0.0199(0.1083)$ \\
\hline $\begin{array}{l}\text { (Change in EBITDA } \\
\text { from prior } \\
\text { year) / (total } \\
\text { beginning period } \\
\text { assets) }\end{array}$ & $-0.1798(0.4844)$ & $2.566(<0.0001)$ & $-0.8081(0.0813)$ \\
\hline $\begin{array}{l}\text { (Change in sales from } \\
\text { prior year) / (total }\end{array}$ & $-0.2489(0.1998)$ & $\begin{array}{l}-0.4611 \\
(<0.0001)\end{array}$ & $0.0051)$ \\
\hline
\end{tabular}

Journal of Corporate Finance, Vol. 16, No. 1 (February 2010): pg. 38-52. DOI. This article is (c) Elsevier and permission has been granted for this version to appear in e-Publications@Marquette. Elsevier does not grant permission for this article to be further copied/distributed or hosted elsewhere without the express permission from Elsevier. 
NOT THE PUBLISHED VERSION; this is the author's final, peer-reviewed manuscript. The published version may be accessed by following the link in the citation at the bottom of the page.

\begin{tabular}{|c|c|c|c|}
\hline & $\begin{array}{l}\text { Likelihood that a } \\
\text { "conflict" related } \\
\text { reason is given at } \\
\text { outsider's } \\
\text { resignation } \\
\text { announcement }\end{array}$ & $\begin{array}{l}\text { Likelihood that a } \\
\text { "busy" related } \\
\text { reason is given at } \\
\text { outsider's } \\
\text { resignation } \\
\text { announcement }\end{array}$ & $\begin{array}{l}\text { Likelihood that } \\
\text { an outside } \\
\text { director leaves } \\
\text { with no public } \\
\text { announcement }\end{array}$ \\
\hline \multicolumn{4}{|c|}{ Parameter } \\
\hline \multicolumn{4}{|l|}{$\begin{array}{l}\text { beginning period } \\
\text { assets) }\end{array}$} \\
\hline $\begin{array}{l}\text { (EBITDA from prior } \\
\text { year) / (total } \\
\text { beginning period } \\
\text { assets) }\end{array}$ & $-0.2499(0.0901)$ & $\begin{array}{l}-1.2267 \\
(<0.0001)\end{array}$ & $0.5864(0.0013)$ \\
\hline $\begin{array}{l}\text { Change in (total } \\
\text { accruals / beginning } \\
\text { period assets) }\end{array}$ & $0.8644(0.0067)$ & $-0.4009(0.1106)$ & $-1.3265(0.0007)$ \\
\hline Beta & $-0.962(0.0087)$ & $0.5678(0.0053)$ & $0.2462(0.4307)$ \\
\hline Log of total assets & $0.0756(0.6658)$ & $-0.1345(0.11)$ & $0.0368(0.7926)$ \\
\hline \multicolumn{4}{|l|}{ Statistics } \\
\hline $\begin{array}{l}\text { Likelihood ratio / chi- } \\
\text { square }\end{array}$ & 67.6265 & 386.3025 & 153.3482 \\
\hline $\begin{array}{l}\text { Probability > chi- } \\
\text { square }\end{array}$ & $<0.0001$ & $<0.0001$ & $<0.0001$ \\
\hline$N$ & 1111 & 1111 & 1111 \\
\hline
\end{tabular}

For variable definitions see explanatory notes to Table 4 and Table 6. 
NOT THE PUBLISHED VERSION; this is the author's final, peer-reviewed manuscript. The published version may be accessed by following the link in the citation at the bottom of the page.

Table 8. Market adjusted return performance and frequency of events in the year following the resignation for a sample of 104 firms with outside director resignations from 1990-2003 ( $p$-values in parentheses).

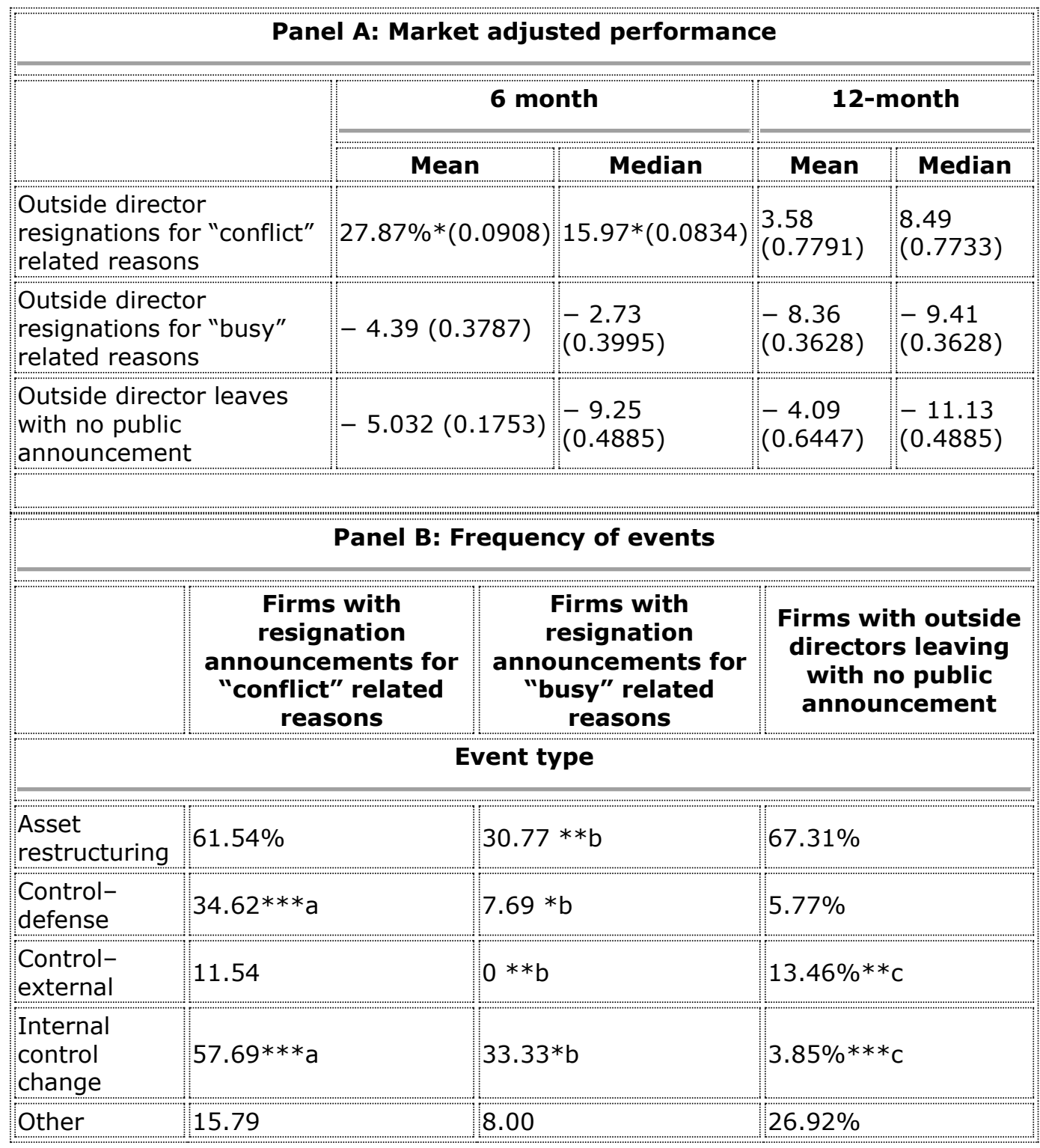

Notes: $*, * *$, and $* * *$ reflect statistical significance at the $10 \%, 5 \%$ and $1 \%$ level respectively.

All data measured in year prior to resignation year. For variable definitions see explanatory notes to Table 6.

a Denotes the statistical significance of difference between firms with "conflict" related resignations versus all others.

Journal of Corporate Finance, Vol. 16, No. 1 (February 2010): pg. 38-52. DOI. This article is (C) Elsevier and permission has been granted for this version to appear in e-Publications@Marquette. Elsevier does not grant permission for this article to be further copied/distributed or hosted elsewhere without the express permission from Elsevier. 
NOT THE PUBLISHED VERSION; this is the author's final, peer-reviewed manuscript. The published version may be accessed by following the link in the citation at the bottom of the page.

b Denotes the statistical significance of difference between firms with "conflict" related resignations versus firms with "busy" related resignations.

c Denotes the statistical significance of difference between firms with "conflict" related resignations versus firms with non-public resignations.

d Denotes the statistical significance of difference between firms with "busy" related resignations versus firms with non-public resignations.

Monthly returns for each firm in the announcement sample as well as the return on S\&P 500 are collected starting in the month following the resignation announcement. For the comparison sample returns are collected in January of the year following the resignation. The market-adjusted performance for each firm for each time period is computed as the geometric mean of $1+$ the firm's performance minus the geometric mean of $1+$ market's performance for 6 or 12 months following the announcement month. Seven firms have less than 6 months of return data. For months that data is no longer available for these firms, their return is replaced with the return on the S\&P 500. To limit the influence of outliers on the statistical test on the difference between market adjusted performance between different types of resignation announcements, market adjusted performance is Winsorized at the $5 \%$ level.

Asset restructuring includes acquisitions, closing a unit, spin-off, issuance or repurchase of equity, or some other type of restructuring events.

Control defenses include adoption of a poison pill, another anti-takeover amendment, or other defensive action.

Takeover related events include takeover rumors, bids, proxy fights, shareholder litigation related to takeover issues, and outside block acquisitions.

Internal management changes include changes in the CEO or other top executives.

Other includes miscellaneous lawsuits and investigations by the SEC.

Journal of Corporate Finance, Vol. 16, No. 1 (February 2010): pg. 38-52. DOI. This article is (C) Elsevier and permission has been granted for this version to appear in e-Publications@Marquette. Elsevier does not grant permission for this article to be further copied/distributed or hosted elsewhere without the express permission from Elsevier. 
NOT THE PUBLISHED VERSION; this is the author's final, peer-reviewed manuscript. The published version may be accessed by following the link in the citation at the bottom of the page.

Table 9. Regression estimates explaining market adjusted return performance and likelihood of events in the year following the resignation for a sample of 104 firms with outside director resignations from 1990-2003.

\begin{tabular}{|c|c|c|c|}
\hline & $\begin{array}{l}\text { Six month market } \\
\text { adjusted } \\
\text { performance in } \\
\text { year after } \\
\text { resignation year }\end{array}$ & $\begin{array}{c}\text { Likelihood of } \\
\text { internal } \\
\text { management } \\
\text { change in year } \\
\text { after resignation } \\
\text { year } \\
\end{array}$ & $\begin{array}{c}\text { Likelihood of } \\
\text { control defense } \\
\text { in year after } \\
\text { resignation year }\end{array}$ \\
\hline \multicolumn{4}{|c|}{ Parameter } \\
\hline Intercept & $-0.79425(0.1635)$ & $-6.9626(0.2056)$ & {$\left[\begin{array}{l}-7.1614 \\
(0.1661)\end{array}\right.$} \\
\hline $\begin{array}{l}\text { "Conflict" related } \\
\text { reason given for } \\
\text { resignation }\end{array}$ & $0.40132(0.0506)$ & $7.3247(0.011)$ & $1.3518(0.4958)$ \\
\hline $\begin{array}{l}\text { "Busy" related } \\
\text { reason given for } \\
\text { resignation }\end{array}$ & $-0.13158(0.4092)$ & $4.0039(0.0879)$ & $\begin{array}{l}-0.7292 \\
(0.6491)\end{array}$ \\
\hline $\begin{array}{l}\text { A resigning outside } \\
\text { director is a } \\
\text { professional director }\end{array}$ & $-0.18941(0.1279)$ & $-2.1729(0.1947)$ & $\begin{array}{l}-0.0915 \\
(0.9278)\end{array}$ \\
\hline $\begin{array}{l}\text { A resigning outside } \\
\text { director is a finance } \\
\text { professional }\end{array}$ & $-0.00705(0.9501)$ & $-1.784(0.1449)$ & $0.8316(0.4074)$ \\
\hline $\begin{array}{l}\text { A resigning outside } \\
\text { director is on audit } \\
\text { committee }\end{array}$ & $0.11624(0.2923)$ & $0.6822(0.5308)$ & {$\left[\begin{array}{l}-0.1381 \\
(0.8932)\end{array}\right.$} \\
\hline $\begin{array}{l}\text { A resigning outside } \\
\text { director is on } \\
\text { compensation } \\
\text { committee }\end{array}$ & $0.07621(0.5401)$ & $-3.6106(0.018)$ & $1.3688(0.206)$ \\
\hline $\begin{array}{l}\text { A resigning outside } \\
\text { director is on } \\
\text { nominating } \\
\text { committee }\end{array}$ & $-0.10991(0.3966)$ & $-0.2725(0.837)$ & $0.5572(0.5935)$ \\
\hline $\begin{array}{l}\text { Firm is delisted in } \\
\text { year after } \\
\text { resignation year }\end{array}$ & $-0.61501(0.0106)$ & $-3.103(0.0601)$ & $\begin{array}{l}-0.3816 \\
(0.8357)\end{array}$ \\
\hline $\begin{array}{l}\text { An asset } \\
\text { restructuring event } \\
\text { occurs in year after } \\
\text { resignation year }\end{array}$ & $-0.2471(0.0201)$ & $1.8047(0.0729)$ & $0.144(0.8784)$ \\
\hline \begin{tabular}{|l|} 
An internal \\
management \\
change event occurs \\
in year after \\
resignation year
\end{tabular} & $0.09756(0.4858)$ & - & $0.7501(0.5242)$ \\
\hline
\end{tabular}

Journal of Corporate Finance, Vol. 16, No. 1 (February 2010): pg. 38-52. DOI. This article is (c) Elsevier and permission has been granted for this version to appear in e-Publications@Marquette. Elsevier does not grant permission for this article to be further copied/distributed or hosted elsewhere without the express permission from Elsevier. 
NOT THE PUBLISHED VERSION; this is the author's final, peer-reviewed manuscript. The published version may be accessed by following the link in the citation at the bottom of the page.

\begin{tabular}{|c|c|c|c|}
\hline & $\begin{array}{c}\text { Six month market } \\
\text { adjusted } \\
\text { performance in } \\
\text { year after } \\
\text { resignation year }\end{array}$ & $\begin{array}{c}\text { Likelihood of } \\
\text { internal } \\
\text { management } \\
\text { change in year } \\
\text { after resignation } \\
\text { year }\end{array}$ & $\begin{array}{l}\text { Likelihood of } \\
\text { control defense } \\
\text { in year after } \\
\text { resignation year }\end{array}$ \\
\hline \multicolumn{4}{|c|}{ Parameter } \\
\hline $\begin{array}{l}\text { A control-defense } \\
\text { event occurs in year } \\
\text { after resignation } \\
\text { year }\end{array}$ & $-0.09346(0.5171)$ & $1.8302(0.1377)$ & - \\
\hline $\begin{array}{l}\text { A control-external } \\
\text { event occurs in year } \\
\text { after resignation } \\
\text { year }\end{array}$ & $-0.21504(0.3645)$ & - $15.5935(0.9721)$ & $3.2293(0.0774)$ \\
\hline $\begin{array}{l}\text { Another type of } \\
\text { event occurs in year } \\
\text { after resignation } \\
\text { year }\end{array}$ & $0.08103(0.5648)$ & $2.5711(0.0508)$ & $2.2432(0.0368)$ \\
\hline $\begin{array}{l}\text { CEO is chairman of } \\
\text { the board }\end{array}$ & $-0.0253(0.8054)$ & $0.9407(0.3811)$ & $\begin{array}{l}-1.2014 \\
(0.1509)\end{array}$ \\
\hline Board size & $0.00118(0.9623)$ & $0.2338(0.2301)$ & $-0.01(0.9534)$ \\
\hline $\begin{array}{l}\text { Percentage of } \\
\text { outside directors on } \\
\text { the board }\end{array}$ & $0.00667(0.0957)$ & $0.0462(0.2188)$ & $-0.01(0.9534)$ \\
\hline $\begin{array}{l}\text { CEO's percentage } \\
\text { stock ownership }\end{array}$ & $0.00747(0.3236)$ & $0.0567(0.3945)$ & $\begin{array}{l}-0.0974 \\
(0.2327)\end{array}$ \\
\hline $\begin{array}{l}\text { CEO's total } \\
\text { compensation as a } \\
\text { percentage of } \\
\text { EBITDA }\end{array}$ & $-0.00108(0.3162)$ & $-0.00939(0.2949)$ & $\begin{array}{l}-0.2051 \\
(0.2985)\end{array}$ \\
\hline CEO's age & $0.0108(0.1419)$ & $-0.0306(0.691)$ & $0.0702(0.2762)$ \\
\hline $\begin{array}{l}\text { Percentage of shares } \\
\text { outstanding held by } \\
\text { outside blockholders }\end{array}$ & $\begin{array}{l}-0.00009601 \\
(0.9816)\end{array}$ & $0.0205(0.6558)$ & {$\left[\begin{array}{l}-0.0185 \\
(0.5924)\end{array}\right.$} \\
\hline $\begin{array}{l}\text { Six month market } \\
\text { adjusted } \\
\text { performance in the } \\
\text { year prior to } \\
\text { resignation year }\end{array}$ & $-0.04557(0.7755)$ & {$[-$} & - \\
\hline Beta & $-0.00142(0.9851)$ & $0.0149(0.9865)$ & $-0.6169(0.346)$ \\
\hline $\begin{array}{l}\text { EBITDA/total } \\
\text { beginning period } \\
\text { assets in year prior } \\
\text { to resignation year }\end{array}$ & - & {$[-0.5869(0.4383)$} & {$\left[\begin{array}{l}-0.2051 \\
(0.2985)\end{array}\right.$} \\
\hline Log of total assets & $-0.02909(0.4697)$ & {$[-0.4055(0.2541)$} & $0.403(0.2236)$ \\
\hline
\end{tabular}

Journal of Corporate Finance, Vol. 16, No. 1 (February 2010): pg. 38-52. DOI. This article is (c) Elsevier and permission has been granted for this version to appear in e-Publications@Marquette. Elsevier does not grant permission for this article to be further copied/distributed or hosted elsewhere without the express permission from Elsevier. 
NOT THE PUBLISHED VERSION; this is the author's final, peer-reviewed manuscript. The published version may be accessed by following the link in the citation at the bottom of the page.

\begin{tabular}{|l|l|l|l|}
\hline & $\begin{array}{c}\text { Six month market } \\
\text { adjusted } \\
\text { performance in } \\
\text { year after } \\
\text { resignation year }\end{array}$ & $\begin{array}{c}\text { Likelihood of } \\
\text { internal } \\
\text { management } \\
\text { change in year } \\
\text { after resignation } \\
\text { year }\end{array}$ & $\begin{array}{c}\text { Likelihood of } \\
\text { control defense } \\
\text { in year after } \\
\text { resignation year }\end{array}$ \\
\hline $\begin{array}{l}F \text {-stat or likelihood } \\
\text { ratio } / \text { chi-square }\end{array}$ & 1.52 & 63.6916 & 36.2374 \\
\hline Probability of $>\mathrm{F}$ & 0.0871 & $<0.0001$ & 0.0286 \\
\hline or $>$ chi-square & 104 & 104 & 104 \\
\hline$N$
\end{tabular}

For variable definitions see explanatory notes to Table 4, Table 6 and Table 8. 